\title{
Operations Strategy Formulation: Shifting from Grasberg Open-Pit Surface Mining to Underground Mining
}

\author{
Rafiq Sulistyo*, Alibasjah Soedjarno**, Togar M. Simatupang** \\ School of Business and Management, Bandung Institute of Technology, West Java - Indonesia
}

\begin{tabular}{|c|c|}
\hline ARTICLE INFO & A B S T RACT \\
\hline $\begin{array}{l}\text { Received: January } 01,2011 \\
\text { Final revision: March } 15,2011\end{array}$ & $\begin{array}{l}\text { PT Freeport Indonesia has decided to alter its mining operations from } \\
\text { open-pit mining to underground mining in Grasberg. A change of }\end{array}$ \\
\hline $\begin{array}{l}\text { Keywords: } \\
\text { operations strategy, } \\
\text { open pit mining, } \\
\text { underground mining, } \\
\text { PT Freeport Indonesia. }\end{array}$ & $\begin{array}{l}\text { mining area focus directly affects its related departments, and even } \\
\text { need new operations strategy to address the transition. Considering } \\
\text { its long-term run of mining operations, its strategic issues are assessed } \\
\text { by using Slack and Lewis operations strategy model, and decisions } \\
\text { are made through the Quantitative Strategic Planning Matrix (QSPM) } \\
\text { tool. Previously, the assessment of company's current business and } \\
\text { corporate strategy was conducted by applying SWOT analysis and } \\
\text { complemented with the Strategic Factors Analysis Summary (SFAS) as } \\
\text { the point-of-reference of the operations strategy. }\end{array}$ \\
\hline
\end{tabular}

Corresponding author:

(C) 2011 IRJBS, All rights reserved.

*rafiq_sulistyo@fmi.com

*alibasjah soedjarno@yahoo.com

****togar@sbm-itb.ac.id

$\mathrm{M}$ ine Electrical Maintenance (or Mine Electrical) is a new department, under the Mine Maintenance Division, PT Freeport Indonesia (PTFI). It was a joint force of Grasberg and Underground Electrical sections. According to mine production forecast released in early 2011, the Grasberg open pit mine was planned to continue until 2017, due to very limited ore left to be mined from the surface that makes it uneconomical and to some extent: unsafe. The ore-body will then be mined from below through underground. It has brought challenge to Mine Maintenance that is responsible for all maintenance activities of equipments operating in both surface and underground mines, and mainly Mine Electrical the unit of analysis in the project, as it has to prepare resources to face the focus shifting properly.

The department has to formulate a strategy in order to face this transition smoothly, operationalwise and manpower-management-wise, because while adding people to the underground is a 
must, support to surface mine production cannot be abandoned either at all the sudden. Balance is the keyword for successful transition as hiring too many employees to fill underground slots will create another problem when Grasberg eventually closes as there will an excessive workforce around than needed. There will be decision-making on how this manpower requirement can be fulfilled without causing other operation suffers; how to better managed all equipment-related works and service requests in a more advanced but easyto-handle system that will ensure target-budget conformity and easy tracking for both customers and maintenance crews. There is also issue about the lack of proper Key Performance Indicator (KPI) to measure the service-based works, causing the departments difficult to improve that dimension of its tasks. Bottom line, Mine Electrical management has to set up a long-term operations strategy in order to make a smooth transition of its operations aligning it with PTFI management mission, objectives and the ever-dynamic circumstances of commodity market, while at the same time taking significant efforts to improve particular dimensions of its performance.

Operations strategy reconciles market requisition with operations resources in the form of decisions pattern that shape long-term capabilities of the operations (Slack and Lewis, 2008: 18). The aims of this project are to provide clear steps for Mine Electrical management before, during and after the transition period, to assess overall capacity required by operations and the way to fulfill it, to assess the condition of current work reques management system and recommendation for improvement and to assess the issue regarding proper KPI to measure service-based works In the following, after assessing PTFI current business and corporate strategy using strategic management model presented by Wheelen and Hunger (2008), operations strategy formulation started with business issue exploration and analysis to have better understanding and come up with alternative solutions. Using the pro-contra analysis and Quantitative Strategic Planning Matrix (QSPM), each alternative would then be assessed to find the best one that will serve as the operations strategy. It would be followed by detail implementation plans complete with estimated timeline and person in charge during the execution.

\section{Company Profile}

PTFI is a copper and gold mining company located in Papua, the easternmost province of Indonesia. It started operation in the country after signing Contract of Work (COW) with Government of Indonesia in 1967. PTFI is owned by FreeportMcMoRan Copper \& Gold Inc. (FCX) which holds $81.28 \%$ of its shares, the GOI (9.36\%) and PT Indocopper Investama (9.36\%). FCX is the world's largest publicly traded copper company. Based in Phoenix, Arizona, United States, the company mines geographically diverse, long-lived reserves of copper, gold and molybdenum. It performs operations through some major affiliates: PTFI, Freeport-McMoRan Corporation and Atlantic Copper.

Right now, PTFI applies two mining techniques, open-pit (surface mine) and underground. Crushed ore from both areas is transported to the mill trough a series of conveyor and ore passes. Combined crushing techniques are used, including the use of Semi Autogenously Grinding (SAG) and Ball Mill to crush ore to become very fine grinded sand. Next, there is flotation process using reagent, an alcohol and lime-based chemical, to separate concentrate containing copper, gold and silver, where these minerals will float to the surface and then skimmed-off as final product. The remainder of the rocks that doesn't have economical value, the tailings, will settle at the bottom of the flotation cell as sediment, and will be released through river flow to the Modified Ajkwa Deposition Area (ModADA) in lowland area. As for the concentrate, it will flow from the mill to dewatering plant in Amamapare port through a 110-km-pipeline. It will then be stored and shipped to smelters around the world.
Although Grasberg open-pit mine is currently the biggest contributor to PTFI production output, it is expected to continue only until end 2017. Thus, the future of the company will lie on the underground mines. Other than DOZ and Big Gossan that's already in production phase, there are the GBC, Deep Mill Level Zone (DMLZ) and Kucing Liar that are currently in development. These mines are presented in Figure 1 .
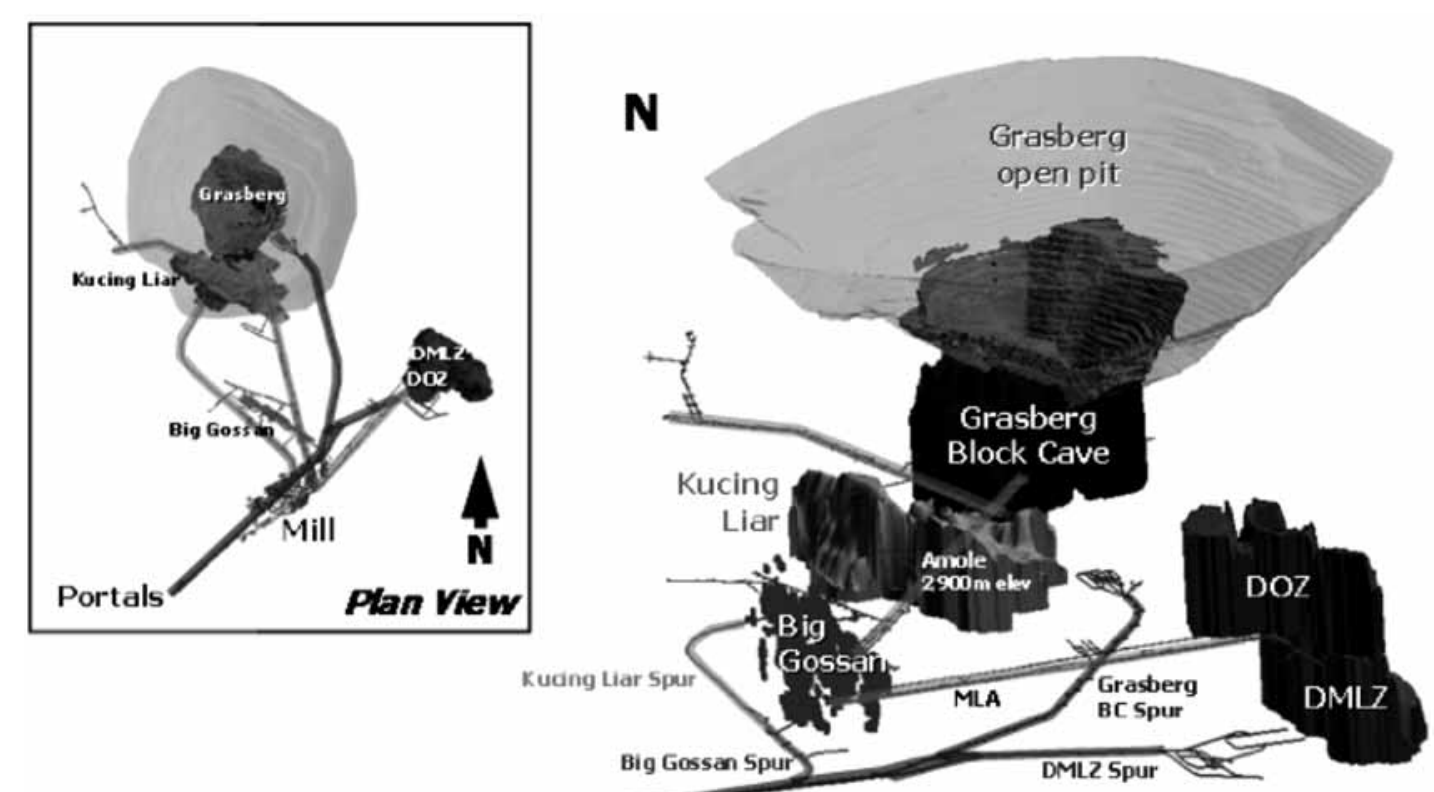
(at Ridge Camp)

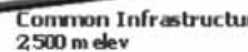

Figure 1. PTFI Mine Ore Bodie

Table 1. Mine Electrical Major Equipments Responsibility

\begin{tabular}{lcc}
\hline Equipments & Area & Quantity \\
\hline Shovel & GRS & 12 \\
\hline Drill & GRS / UG & 75 \\
\hline Gen Set/Compressor & GRS / UG & 49 \\
\hline Over Head Crane & GRS / UG & 64 \\
\hline Switchgear/Ring Main Unit (RMU) & GRS / UG & 38 \\
\hline Substation/Load center/Transformer & GRS / UG & 161 \\
\hline Loader & UG & 144 \\
\hline Haul Truck & UG & 271 \\
\hline Rock Breaker & UG & 26 \\
\hline Ore Chute & UG & 30 \\
\hline Ventilation Fan & UG & 210 \\
\hline
\end{tabular}

The unit of analysis in this project is Mine Electrica Maintenance, which has the responsibility to perform maintenance works on electrical equipment (or electrical-side of equipment) and provide service to various customers in the form of new/additiona electrical installation, electrical wiring/function modification, moving/removing, part replacement troubleshooting and engineering design/drawing. Major equipments under Mine Electrical is shown in Table 1 
Equipment-based maintenance activities are raised according to routine schedule set in system called Ellipse and then trigged by a certain period or operating hours, inspections result or breakdown events. These kinds of activity mostly are preventive maintenance (PM) and reactive maintenance (breakdown). Service works are created based on user/customer requests or ongoing projects. In total number and duration, service work orders are almost equal to those equipment maintenance ones, with a ratio reaches $48: 52$. This characteristic has made Mine Electrical different from most of departments in Mine Maintenance division. For both surface and underground areas, the role of the department is critical to provide electric power and maintenance service to equipments, buildings, shops and lightings.

\section{METHODS}

The research method used is a combination between the strategic management model presented by Wheelen and Hunger (2008) and operations strategy model introduced by Slack and Lewis (2008). The desired final output is the operations strategy and implementation plan for Mine Electrical in response to the shifting of mining focus from Grasberg to underground mines. The strategic management model will be used to derive corporate strategy and business strategy which will serve as guidance and reference for the operations strategy developed later.

Analysis began with environmental scanning: external and internal environment. External environmental scanning was done using Porter's Five Forces and PEST analysis. Internal environment scanning tries to analyze organization's structure, culture and resources. The results of this scanning will be used as the base of SWOT analysis complemented with the use of Strategic Factors Analysis Summary (SFAS). Next, there will be review and assessment of company's current mission, vision, values and objectives. This stage is important to compare between target and resources because strategy is a comprehensive master plan that states how the corporation will achieve its mission and objective by effectively manage environmental opportunities and threats in light of corporate strengths and weaknesses (Wheelan and Hunger, 2008: 14 \& G-9). Output of this stage is formulation of corporate strategy and business strategy. Beckman and Rosenfield (2008: 17) state that "corporate strategy identifies the industries and markets in which a firm will compete". It is usually categorized as growth, stability or retrenchment. "Business strategy is competitive and cooperative strategies that emphasize improvement of the competitive position of a corporations' products or services in a specific industry or market segment" (Wheelen and Hunger, 2008: G-1).

The next step will be formulating functional strategies, based on the corporate and business strategy. In this project, the scope is only operations strategy. As mentioned before, model developed by Slack and Lewis (2008) was used in this stage. This model is shown in Figure 2. Content of operations strategy is mainly about an interaction between operation's performance objectives and the decisions that need to be made regarding its resources, processes and capabilities. In this project performance objectives are determined by upper management target and influenced by the corporate goals and also from customer needs. Competition is non-existence neither does market positioning, since Mine Electrical is a department in a company. Performance objectives will refer to what the model offers: quality, speed, dependability, flexibility and cost. Operations decision areas are concerned with the capacity, process technology and development and organization.

After all problems in each decision areas were analyzed, several alternatives solution will be offered. All alternatives will then be elaborated and also analyzed to better understand the pros and cons of each. Decision will then be made using the Quantitative Strategic Planning Matrix (QSPM). "QSPM is a strategic tool which is used to evaluate alternative set of strategies. The QSPM

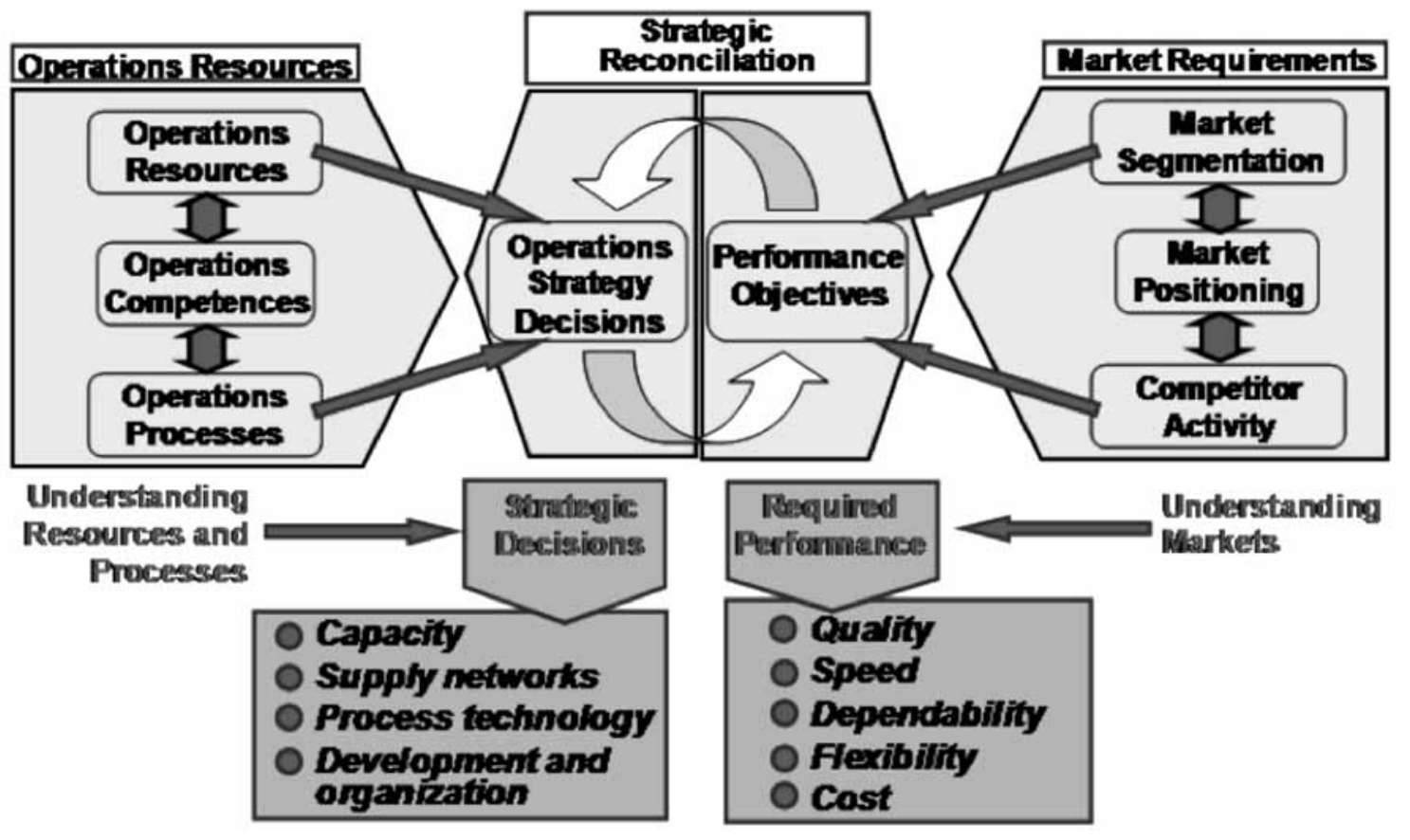

Figure 2. Operations Strategy Model by Slack and Lewis (2008)

combine the intuitive thinking of managers with the analytical process to decide the best strategy for the organization success." (www.mba-tutorials.com, 2009). Key factors used as comparison parameter were the performance objectives. The weight for each key factor was determined from historical data and discussion with several key team members. Then, each of the alternative solution was rated by its influence to the key factors, and an Attractiveness Score (AS) was given. The range for Attractiveness Score is $1=$ not attractive, $2=$ somewhat attractive, $3=$ reasonably attractive, $4=$ highly attractive. Total Attractiveness Score (TAS) is the product of weight and AS. After all examinations are done, the Sum Total Attractiveness Score (STAS) is calculated and alternatives solution with highest STAS is the one to be chosen.

RESULTS AND DISCUSSION

Business and Corporate Strategy

Assessment of PTFI current business and corporate strategy started with external and internal environmental scanning. PEST analysis and Porter' Five Forces were used to analyze external factors then combined with the internal situation analysis in the SWOT and SFAS. Summary of PEST analysis is shown in Table 2, while summary of Porter's Five Forces analysis is given in Figure 3. Importan points include:

- Indonesia's volatile and unstable political situation provides risk to PTFI operations Political instability might lead to company's property destruction and interruption of activities.

- Company's revenue is highly influenced by production output and commodity prices. Copper price averaging $\$ 3.42 / \mathrm{lb}$ during 2010 ranged from $\$ 2.76 / \mathrm{lb}$ to $\$ 4.42 / \mathrm{lb}$. Gold reached $\$ 1,500 / \mathrm{oz}$ on third week of April.

- Copper has been benefited from the emergence of India and China as the next industria countries. 
Table 2. PEST Analysis PT Freeport Indonesia

\begin{tabular}{|c|c|}
\hline Political -Legal & Economical \\
\hline Uncertainties in Indonesia's political situation. & Fluctuative but increasing commodity prices \\
\hline New Mining Law that might affect the current COW & $\begin{array}{l}\text { High demand of copper from industrial countries, } \\
\text { especially China }\end{array}$ \\
\hline $\begin{array}{l}\text { Constant protest and demonstration on PTFI existence } \\
\text { in Papua }\end{array}$ & Instability of foreign currencies \\
\hline Complex and evolving environmental law & Limited non-renewable energy sources \\
\hline \multirow[t]{2}{*}{$\begin{array}{l}\text { Regulation on greenhouse gas emission and climate } \\
\text { change }\end{array}$} & Increasing inflation rate from end of 2010 \\
\hline & US debt condition \\
\hline Social & Technology \\
\hline $\begin{array}{l}\text { Unrest among community after numeruous shooting } \\
\text { since } 2009\end{array}$ & \multirow[t]{2}{*}{$\begin{array}{l}\text { Not many breakthrough in mining techniques } \\
\text { developed in last decade }\end{array}$} \\
\hline Sporadic terror from separatist groups of Free Papua & \\
\hline Illegal panners & \multirow{2}{*}{$\begin{array}{l}\text { Technological developed vastly for mining suppor } \\
\text { activities such as remote control, automation, high } \\
\text { capacity/capability equipments }\end{array}$} \\
\hline Most of the local tribe in nearest area still illiterate & \\
\hline \multicolumn{2}{|l|}{ High number of malaria and HIV/AIDS case in Papua } \\
\hline Local and national media coverage of PTFI operations & \\
\hline
\end{tabular}

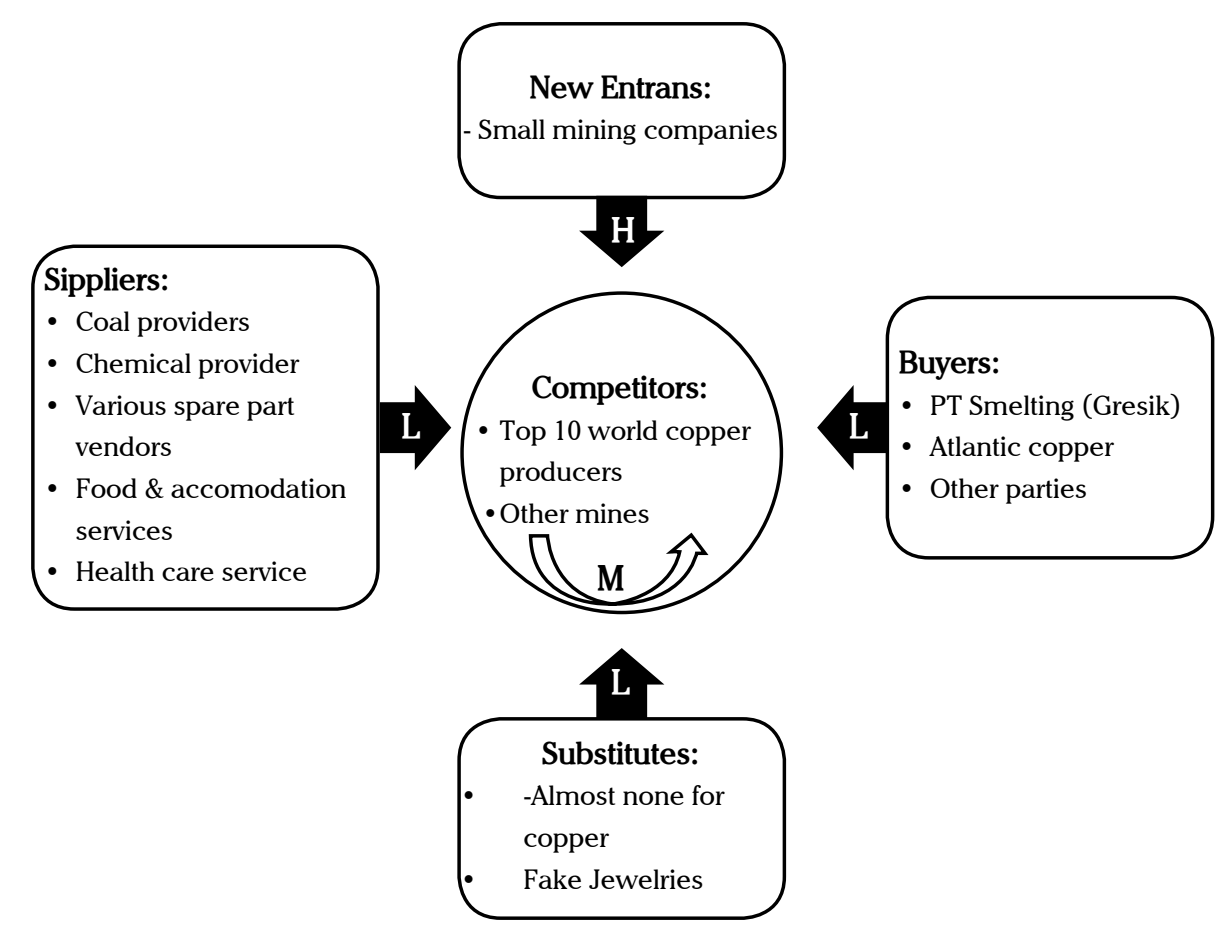

Figure 3. Porter's Five Forces Analysis for PTFI

Table 3. FCX Selected Financial Ratio

\begin{tabular}{lcc}
\hline Financial Indicator & $\mathbf{2 0 1 0}$ & $\mathbf{2 0 0 9}$ \\
\hline Current Ratio & 2.62 & 2.48 \\
Quick Ratio & 1.64 & 1.49 \\
Assets Turnover & $65 \%$ & $58 \%$ \\
Profit Margin & $29 \%$ & $23 \%$ \\
Return on Assets & $19 \%$ & $14 \%$ \\
Return on Equity & $38 \%$ & $33 \%$ \\
Dept Equity Ratio & 1.02 & 1.42 \\
\hline
\end{tabular}

- Since mid July 2009, there have been 12 shooting incidents inside PTFI COW area causing 5 casualties that has led to unrest within community.

- Mining techniques haven't gone far for the last decades, causing no significant breakthrough occurs and usually just small production improvement.

- Top 10 copper producers are comprised 50\% of total worldwide copper production. FCX ranked second among these firms with $9 \%$ contribution

Internal environmental scanning result highlights include:

- From FCX selected financial ratio shown in Table 3 , it can be seen that 2010 has been an improvement year compared to 2009 , especially due to the increase in copper and gold price. - PTFI site is one of the safest mine in the world, supported strongly by its concern in safe production. In 2006 and 2010, PTFI succeed in maintaining the fatal rate to zero. One of the biggest challenges to this, workers factor aside, is operation locations, which are located in unusually difficult terrain in a very remote area.

- On the deposit side, PTFI has huge ore reserve that can be mined until the end of the Contract of Work, including the two 10-year extensions. The deposit represents opportunities to stay among the top players of copper and gold industries in the world for years to come.

- PTFI is equipped with high-skilled and experienced employees, combined with strong motivated freshmen as the next generation of the mine operations. It provides broad range of development programs for its employees complemented with offsite training programs whenever required.

- PTFI has several key Corporate Social Responsibility (CSR) programs as stated in FCX 2010 Form 10-K (2010: 28):

- job training programs

- basic education programs

- public health programs (including malaria control)

- agricultural assistance programs

- small and medium enterprise development programs

- cultural preservation programs, and many others.

- PTFI also participated in Partnership Fund, where it provide one percent of its annual revenue for development programs aimed at local people. PTFI contributed $\$ 64$ million in 2010, $\$ 59$ million in 2009 and \$34 million in 2008 .

- Some less supporting facts about the operations and area including: only one land road available from lowland to highland and from highland to mine area. Any disruption to part of the road will lead to halt of material and employee transportation and even the hal of operations. Underground mine manpower requirement ramp-up also means that prope and adequate accommodation available for all employees and contractors, which currently still significantly lack of capacity. 


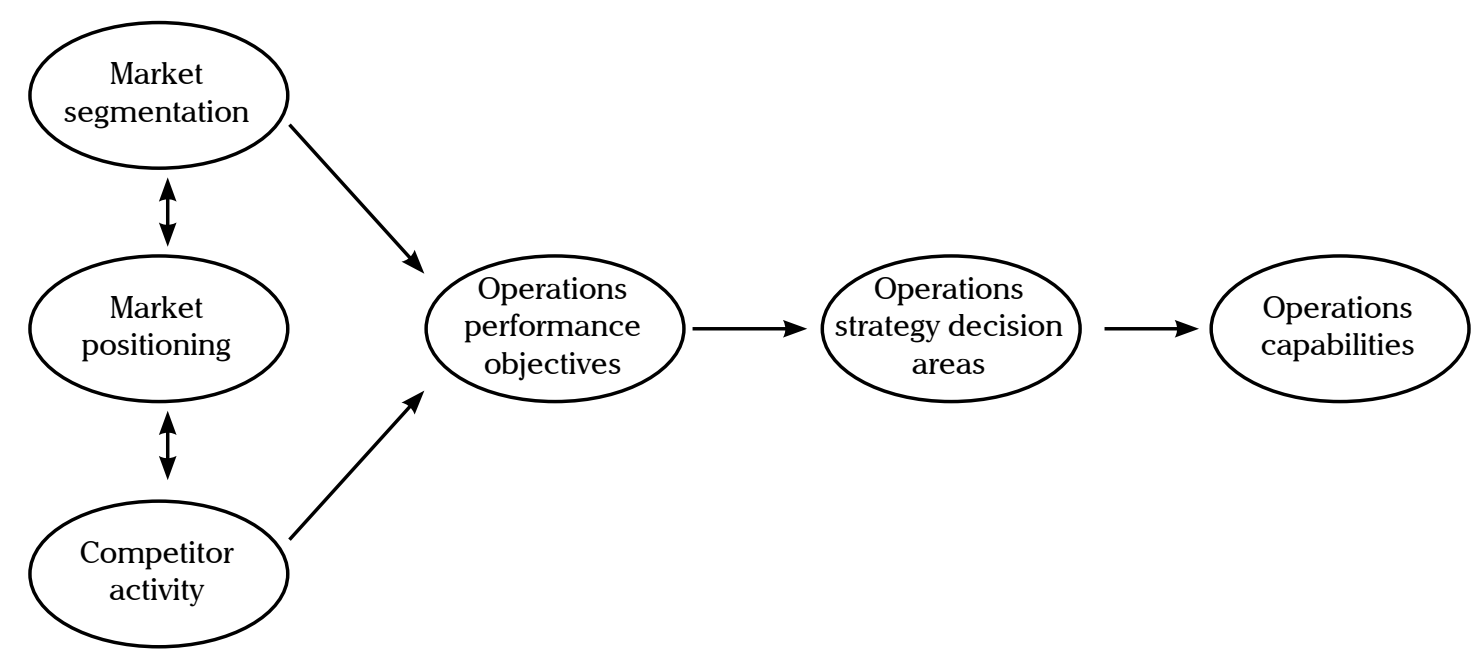

Figure 4. The Allignment of Operations Resources with Market Requirements

The SWOT-SFAS analysis of PTFI is shown in Appendix 1. Assessing mission, vision (IR Guidebook, 2009: vii - viii) and objectives of the company and comparing them to the SWOT-SFAS result, showed that they are still in line with the situation in which the organization is presently facing, external and internal. So, there's no requirement to revise them to adapt to the current environment.

Recalling PTFI mission and vision about being "the lowest-cost" copper producer, indicates the company's intend to choose lower cost as its competitive advantage. Also, since copper is a common commodity and PTFI sells to numerous smelting facilities, the competitive scope is broad. Thus, the business strategy that suits the company best is cost leadership.

While for corporate strategy the most logical directional corporate strategy that PTFI will choose is Growth. There are huge opportunities to produce higher revenue due to market condition. Combining this momentum with PTFI internal strong resources, organizational capabilities and especially ore deposits, there's big probability that the plan will go on successfully. According to Wheelen and Hunger (2008: 169), "a company can grow horizontally through internal development or externally through acquisition or strategic alliances with other firms in the same industry". For PTFI, horizontal growth means developing its internal resources, in this case the ore deposits, by investing capital to improve the capabilities of the productive mines and perform development projects in the future underground mines (DMLZ, GBC, Kucing Liar)

\section{Operations Strategy}

Every operations has objective to align market requirement and operations capability. This alignment is called "fit", or approximate balance between required market performance and actual operations performance (Slack and Lewis, 2008: 228). The alignment can be approached in two ways, first by identifying current market requirements and then align the internal operations resources; second by understanding resources and processes and identify core capabilities and then seek market opportunities that align with those capabilities. The flow as discussed by Slack and Lewis (2008: 232) is presented in Figure 4. Note that it is only for the first approach that will be used in this project.

The Slack and Lewis model derives market requirements from market segmentation (customer needs), market positioning and competitor's actions. In Mine Electrical case, market positioning and competitor's actions are not applicable. Customer needs defined as all items required by the customers which are performance target from the upper management set to the department and all dimensions of customers' requests. List of customers with their needs is shown in Table 4. As for Mine Electrical, the performance is measured by certain parameter targets which are availability, Mean Time between Failure (MTBF), KPIs (five of them) and also target of other department that it supports. All of these targets are shown in Table 5. In terms of supporting production targets of Surface Mine and Underground Mine division, as mentioned before, Mine Electrical has vital role in providing power to equipments, buildings and workshops, also in performing maintenance work on the equipments. For example, to achieve 154,000 tpd target in surface mine, the department, in this case surface power distribution section, plays important part in ensuring that electric power available through transmission lines from switchgears, to substations, from substations to electric shovels. The section also responsible to connect and disconnect trailing cable from substation to shovels whenever they plan to move or relocate, to maintain the switchgears and substations and to repair/

perice to trailing cables. The electric shovel section is responsible to the availability of the shovels by doing routine maintenance and troubleshooting. Dispatch system maintenance technicians are responsible to the smooth operation of the dispatch system components: the display, the communication network, etc. It is a complex work and involves different sections in Mine Electrical and also different departments in Mine Maintenance, to accomplish the preset target.

Analysis of current operations resources capabilities:

- Experienced workforce, $51 \%$ of employee have more than 10 years, $41 \%$ of those have 15 years or more of service.

- Excellent process know-how especially for old equipments and tasks. Years-of-experience in performing similar projects and maintenance on same equipments has developed in-depth knowledge and skill required and the team has improved the learning curve. There's challenge though to upgrade the knowledge and skil especially to new and updated systems and equipments through training and hands-on experience.

- Close relationship to customers.

Table 4. Mine Electrical Main Customers' Needs

\begin{tabular}{ll}
\hline Main Customers & Needs \\
\hline Mine Maintenance Management & Availability, MTBF, KPI \\
\hline Surface Mine Division & Production target, regular requests, safety \\
\hline Underground Mine Division & Production target, regular requests, safety \\
\hline Loading and Support Mtc Dept. & Availability, regular requests, safety \\
\hline Haulage, Welding \& Tire Service Dept. & Availability, regular requests, safety \\
\hline Underground Mechanical Mtc Dept. & Availability, KPI, regular requests, safety \\
\hline Concentrating Division & Production target, availability \\
\hline Human Resources and Industrial Relations Dept. & Regular requests, safety \\
\hline Management Information System (MIS) Dept. & Regular requests, safety \\
\hline PT Redpath Indonesia & Production target, regular requests, safety \\
\hline Central Service Division & Project target, regular requests, safety \\
\hline Quality Management Services Departement & Regular requests, safety \\
\hline Supply Chain Management Division & Regular requests, safety \\
\hline
\end{tabular}


Table 5. Availability, KPI and Customers' Target for 2011

\begin{tabular}{lc}
\hline Availability/KP/Department & Target \\
\hline Electric Shovels availability & $88 \%$ \\
\hline GRS Electric Drills availability & $80 \%$ \\
\hline Switchgear/Substation/Load Center availability* & $98 \%$ \\
\hline Service Tram \#1 availability & $92 \%$ \\
\hline Service Tram \#2 availability & $95 \%$ \\
\hline UG Electric drills availability & $83 \%$ \\
\hline UG Remote Loaders availability & $80 \%$ \\
\hline Rock Breakers and Loading Points ava & $85 \%$ \\
\hline Ventilation Fans availability & $85 \%$ \\
\hline KPI \#1 - Scheduled Work Order Compliance* & $80 \%$ \\
\hline KPI \#2 - PM Schedule Compliance & $90 \%$ \\
\hline KPI \#3 - Planned Work Order Raised* & $60 \%$ \\
\hline KPI \#4 - PM Effectiveness* & $85 \%$ \\
\hline KPI \#5 - Actual Man Hours for Planned Work* & $60 \%$ \\
\hline Surface mine & $154,000 \mathrm{tpd}$ \\
\hline UG - DOZ Mine & $80,000 \mathrm{tdp}$ \\
\hline UG - Big Gossan Mine & $2,500 \mathrm{tdp}$ \\
\hline UG - DMLZ Mine & $1334 \mathrm{~m} / \mathrm{month}$ \\
\hline
\end{tabular}

- Strong support from vendors and manufacturers. PTFI is considered as major customer by vendors and manufacturers due to its buying power and purchase volume. Mine Electrical has advantage of this condition because suppliers tend to give more serious attention on the department needs and requirements.

- Adequate operational budget. Annually, in total, there's adequate operational budget available to be used for maintenance process: for the equipments and for the crews.

- Support of proper tools. PTFI provides a wide range of tools ready to be ordered by each department requires from the warehouses. In case a special tool is needed, they can be acquired through direct charge process from suppliers.

- Access to new technology updates and information. Frequent updates of what is happening in the industry, is required to keep the team well-informed and make adjustments as necessary.

- Ability to adjust schedule and resource requirement. One of the challenges of performing PM is the ability to execute it on schedule. Operational priority often gets in the way to accomplish this. Team ability to adjust to the issue and appropriately re-assign crews and resource to other location and task.

- Good reputation among customers. Beside the fact that the department is the sole service provider of all electrical-related work orders in the mine, it is also known for consistently delivering good results and service to the customers. This information is gathered from feedback of customers through emails or supervisors.

The performance objectives demanded from
Mine Electrical by customers in priority order are speed, quality (including reliability), dependability, flexibility and cost. On the other hand, management sees quality as the higher priority. Speed and quality are the most important things especially when dealing with the production groups, because they always going for the production target, which is the ore. This fact revealed based on the feedback from customers and interview with Mine Electrical Manager, Agung Hariyadi, on 10th March 2011 as quoted below:

"One of the disadvantages in carrying out our duty is the fact that our task still considered as non-core business although in reality our role is inseparable to the production chain. The core is ore. So it's a bit hard to be professional in terms of bringing the best quality to our work. Our clients opt for speed and flexibility, while our management asks for reliability (quality and dependability)... Cost is not a big concern at this point. As long as you can justify each of the expenditure, the money is there to spend. Also, so far, customers almost never complain about the cost they have to spend to buy materials and spare parts or to fund their projects.'

Aspects to be considered from each performance objective are:

- Quality: the specification conformance between planned/requested and actual delivered, the conformance to standard/reference, and the reliability of work result

- Speed: the time required for PM on equipment to be executed, the total time required to repair equipment/installation and the total time to complete a project or work request.

- Dependability: the difference between promised completion time of work given to customers and the actual completion time.

- Flexibility: the ability to change the variety of product and services, the level of the operation's aggregated output, and planned or assumed delivery dates.

- Cost: any financial input to the operation that enables it to produce its products and services: operating expenditure, capital expenditure an working capital (Slack and Lewis, 2008: 41).

\section{Capacity Strategy}

Capacity strategy is defined as "the set of decisions concerned with how operations configure and change their overall capacity in order to achieve a particular level of output potential" (Slack and Lewis, 2008: 69 - 70). Main focus would be the decision on overall level of operations capacity, because the number and size of sites, the location of sites and capacity change were either not a significant issue or already predetermine by the department. Overall capacity is analogized as the total manpower required running the operations, because Mine Electrical is in the business to provide services. The number then will be distributed based on the how many manpower required for each equipment in each area.

As reference, this project will use data forecas of equipment requirement in both surface and underground mines. Each component of the forecast has certain ratio that can be used to convert equipment number to manpower number. Fo baseline calculation, the number and ratio used for year 2011 will be used as comparison. As Grasbers open-pit mine will last until 2017, calculation will cover manpower requirement up to that year. Manpower distribution will also refer to the current organization chart added with necessary adjustment for each year. Number of equipments forecast and men/machine ratio for each equipment are shown in Table 6. The number of manpower required for non-equipment factors is dynamic, subject to mine development or activity decrease in the respective areas, but as comparison, 2011 figures will be used. Current ratio used is shown in Table 7 . Actual manpower requirement for each of the nonequipment category was assessed by calculating type and number of job per day, manpower required per job and duration needed to perform each job. End result was the proper manpower number pe shift. Assumption used was that the work roster 
Table 6. Equipment Forecast and Men/Machine Ratio

\begin{tabular}{lcccccccc}
\hline \multirow{2}{*}{ Equipment } & Man/Machine & 2011 & 2011 & 2013 & 2014 & 2015 & 2016 & 2017 \\
\cline { 3 - 9 } & Ratio & Units & Units & Units & Units & Units & Units & Units \\
\hline Axera 5 & 0.5 & 1 & 0 & 0 & 0 & 0 & 0 & 0 \\
\hline Axera 7 & 0.5 & 28 & 31 & 30 & 29 & 30 & 30 & 30 \\
\hline Axera T08-290 & 0.5 & 6 & 5 & 5 & 5 & 5 & 5 & 4 \\
\hline Axera T08-360 & 0.5 & 5 & 6 & 7 & 7 & 7 & 7 & 5 \\
\hline Cubex & 0.5 & 8 & 8 & 8 & 8 & 4 & 4 & 8 \\
\hline Robolter 5 & 0.5 & 3 & 7 & 5 & 4 & 4 & 4 & 4 \\
\hline Cabolter 7 & 0.5 & 5 & 5 & 5 & 5 & 5 & 5 & 5 \\
\hline Solo 7-15 & 0.2 & 3 & 5 & 5 & 9 & 13 & 14 & 14 \\
\hline Compressor & 0.2 & 12 & 14 & 16 & 20 & 20 & 20 & 20 \\
\hline Main Fans & 0.1 & 22 & 22 & 22 & 24 & 24 & 24 & 24 \\
\hline Auxiliary Fans & 0.03 & 188 & 188 & 200 & 200 & 240 & 240 & 240 \\
\hline Welding Machine & 0.05 & 45 & 60 & 60 & 60 & 60 & 60 & 60 \\
\hline Hi-Vac & 0.2 & 1 & 2 & 2 & 2 & 2 & 2 & 2 \\
\hline Lighting Plants & 0.2 & 2 & 2 & 2 & 2 & 2 & 2 & 2 \\
\hline Fixed Crane & 0.1 & 28 & 31 & 34 & 38 & 38 & 38 & 38 \\
\hline Rockbreakers & 0.3 & 26 & 26 & 28 & 32 & 32 & 34 & 38 \\
\hline Ore Chutes & 0.2 & 30 & 30 & 32 & 34 & 34 & 42 & 46 \\
\hline Remote Control Loaders & 0.5 & 10 & 10 & 12 & 12 & 12 & 12 & 12 \\
\hline 36 Ton Locomotive & 1.5 & 6 & 6 & 10 & 10 & 10 & 10 & 12 \\
\hline 43 Ton Locomotive & 1.5 & 1 & 1 & 1 & 6 & 8 & 10 & 12 \\
\hline Battery Locomotives & 1.5 & 0 & 0 & 0 & 0 & 0 & 0 & 4 \\
\hline Battery Stations & 2 & 0 & 0 & 0 & 0 & 0 & 0 & 1 \\
\hline Surface Substation Mtce & 0.25 & 17 & 17 & 17 & 17 & 17 & 17 & 17 \\
\hline SHvl Electrical & 2.45 & 11 & 11 & 8 & 8 & 4 & 3 & 0 \\
\hline & & & & & & & & \\
\hline & & & & & & & \\
\hline
\end{tabular}

would be managed as three shifts per day, consists of four crews (each day, one crew will be on day off schedule). Per shift, effective work hours are seven hours, considering meal break and travel time on early and end of shifts. When required, a steady day personnel could be established to maintain the work better, especially for area where most projects are likely to be executed in during daylight. For groups where troubleshooting are part of their job description, an extra man hours to troubleshoot, $10 \%$ of subtotal man hours, is added to the equation. Samples of calculation are given to better explain how the process went, from describing the responsibility of the group, area/equipment of responsibility, average men and duration required for each task to finally come up with the ideal men/ shift ratio number.

HV and LV Power Distribution - Maintenance. This group has responsibility to maintain and perform power expansion projects in DOZ. Due to their similarity in working process, the $\mathrm{HV}$ and $\mathrm{LV}$ power distribution and maintenance groups can be considered as one team. So, there will be 7 crews available per shift. The job description includes:

- Pull and install cable, distribution panel to development areas where electric drills need to operate and other areas where sections of

Table 7. Manpower Requirement Ratio for Non-Equipment (Current)

\begin{tabular}{lc}
\hline Non-Equipment/Area & Required \\
\hline HV Power Distribution - Maintenance & $3 /$ shift \\
\hline LV Power Distribution - Maintenance & $4 /$ shift \\
\hline Fixed Plant - Shops \& Lamp Room & $2 /$ shift \\
\hline Tram, Hoist \& Paste Plant & $6 /$ shift \\
\hline Dispatch, Communications \& Instrumentation & $6 /$ shift \\
\hline Big Gossan Power Distribution & $2 /$ shift \\
\hline DMLZ Power Distribution & $2 /$ shift \\
\hline GBC Power Distribution & $2 /$ shift \\
\hline Expansion Mines Construction & $2 /$ shift \\
\hline Power lines & $6 /$ shift \\
\hline Cable Repair & $2 /$ shift \\
\hline Fixed Facility Mtce & $3 /$ shift \\
\hline Dispatch technician & $2 /$ shift \\
\hline Rotation & $4 /$ shift \\
\hline Planners & $5 \%$ \\
\hline Supply Chain Management Division & $4 \%$ \\
\hline
\end{tabular}

the Underground division works and need electrical power;

- Install, move, relocate, remove, maintain the jumbo box, the drill control panel, that follow the drill everywhere it goes;

- Perform maintenance on the load centers, transformers, switchgears, ring main units (RMU), vacuum circuit breakers (VCB) located in DOZ, Big Gossan, DMLZ, GBC and Kucing Liar on monthly and yearly basis including to handle trouble on this equipments.

In average, there are six equipments per day scheduled for monthly preventive maintenance where three persons are required to perform the task in about two hours. Jumbo box related jobs in this area are about six per day, requiring two crews to work in a task that takes averagely three hours (including travel time). Four power expansion projects that take about five hours per job usually handled by three crews. Detail calculation shown below in Table 8. In one day, a total of 146 man hours are required. It is equivalent to 6.9 men per shift (calculated from 146 / 3 shifts 7 hours). Rounding up to 7 men per shift, it can be seen that the ratio still matched of what the upper management uses.

For the moment, the ratio of 3/shift and 4/shif are adequate for the group. But, considering the ramping up of DOZ production in 2015 to cover open-pit production stop in 2017, there has to be an adjustment prior to that year in term of the ratio. DOZ development activities which require more HV power installation, make it sensible to increase the ratio to 4/shift starting 2015 for $\mathrm{HV}$ power distribution - maintenance. The result of this calculation through year 2017 is presented in Table 9 .

Tram, Hoist and Paste Plant. The main responsibility is to perform preventive and reactive maintenance on each of these plants. Service Tram \#1 and $\# 2$, at GBT area, have routine PM schedule each week which in average need eight hours and required four personnel to perform. One crew also needed performs shift inspection for about two 
Table 8. Required Man Hours for HV and LV Power Distribution

\begin{tabular}{lcccc}
\hline \multicolumn{1}{c}{ Job } & Qty & Crew & Duration & Man Hours \\
\hline PM & 6 & 3 & 2 & 36 \\
\hline Jumbo box & 6 & 2 & 3 & 36 \\
\hline Expansion & 4 & 3 & 5 & 60 \\
\hline \multirow{4}{*}{} & & Subtotal & 132 \\
\cline { 3 - 4 } & & Troubleshooting & 14 \\
\cline { 3 - 4 } & & & \\
\cline { 3 - 4 } & & &
\end{tabular}

Table 9. Manpower Requirement Forecast - HV and LV Power Distribution

\begin{tabular}{lccccccc}
\hline \multirow{2}{*}{$\begin{array}{l}\text { Non-Equipment/ } \\
\text { Area }\end{array}$} & 2011 & 2011 & 2013 & 2014 & 2015 & 2016 & 2017 \\
\cline { 2 - 7 } & $\mathrm{N} / \mathrm{S}$ & $\mathrm{N} / \mathrm{S}$ & $\mathrm{N} / \mathrm{S}$ & $\mathrm{N} / \mathrm{S}$ & $\mathrm{N} / \mathrm{S}$ & $\mathrm{N} / \mathrm{S}$ & $\mathrm{N} / \mathrm{S}$ \\
\hline $\begin{array}{l}\text { HV Power } \\
\text { Distribution - } \\
\text { Maintenance }\end{array}$ & 12 & 16 & 16 & 16 & 20 & 20 & 20 \\
\hline $\begin{array}{l}\text { HV Power } \\
\begin{array}{l}\text { Distribution - } \\
\text { Maintenance }\end{array}\end{array}$ & 16 & 16 & 16 & 16 & 16 & 16 & 16 \\
\hline
\end{tabular}

\section{Table 10. Required Man Hours for Tram, Hoist and Paste Plant}

\begin{tabular}{lcccc}
\hline \multicolumn{1}{c}{ Job } & Qty & Crew & Duration & Man Hours \\
\hline Tram PM & 0.14 & 4 & 8 & 5 \\
\hline Hoist PM & 0.05 & 5 & 10 & 3 \\
\hline Tram Inspection & 3 & 2 & 2 & 12 \\
\hline Hoist Inspection & 3 & 2 & 3 & 18 \\
\hline Paste Plant & 1 & 8 & 7 & 56 \\
\hline Projects & 1 & 3 & 7 & 21 \\
\hline & \multicolumn{3}{l}{ Subtotal } & 115 \\
\hline & \multicolumn{3}{l}{ Troubleshooting } \\
\cline { 2 - 4 } & \multicolumn{2}{l}{12} \\
\hline
\end{tabular}

hours. The Big Gossan Hoist is scheduled for PM every three weeks, performed by five crews for ten hours. Similar to the trams, shift inspection by one crew is also performed for two hours. In both areas, electricians also perform building and shops electrical installation inspection and maintenance duty. Paste plant on the other hand is still under
Table 11. Manpower Requirement Forecast - Tram, Hoist and Paste Plant

\begin{tabular}{lccccccc}
\hline $\begin{array}{c}\text { Non-Equipment/ } \\
\text { Area }\end{array}$ & 2011 & 2011 & 2013 & 2014 & 2015 & 2016 & 2017 \\
\hline $\begin{array}{l}\text { Tram, Hoist \& } \\
\text { Paste Plant }\end{array}$ & 32 & 32 & 32 & 32 & 32 & 32 & 32
\end{tabular}

Tram, Hoist \&
Paste Plant 32 32

Table 12. Number of Work Requests in Selected Period

\begin{tabular}{lccc}
\hline \multicolumn{1}{c}{ Periode } & $\begin{array}{c}\text { Jan-Nov } \\
\mathbf{2 0 1 0}\end{array}$ & $\begin{array}{c}\text { Jan-Apr } \\
\mathbf{2 0 1 1}\end{array}$ & 2015e \\
\hline $\begin{array}{l}\text { Total number of work } \\
\text { request }\end{array}$ & 25,000 & 9,000 & 43,000 \\
\hline Average per day & 77 & 78 & 118 \\
\hline Average per shift & 26 & 26 & 39 \\
\hline
\end{tabular}

Forecast through 2017 is shown in Table 11. In the forecast, other than six crews per shift, eight personnel have been added to the equation to represent the need of steady day crews in paste plant and trams. Because although Table 2-19 shows plenty of time still remain in each day (12 man hours), the fact that these plants are located separately (trams at GBT, hoist and paste plant switch area quickly or move to other site to provide support when problem occurred. With additional steady day crews, it is hoped that projects can be executed during day shift, so shift crews can focus on maintenance duty. These plants are planned to still be operating under the same condition as today by 2017. There will be no changes in the functionality or major modifications on the system that will require additional manpower. Thus, from 2011 to 2017 the total manpower will be flat at 32 personnel. Calculation summary of manpower requirement for equipment and non-equipment category is presented in Appendix 2.

\section{Process Technology Strategy}

The issue that is closely related to the increased volume of jobs in underground mine areas and in need of the touch of technology is handling of the abundant work requests in both surface and in Big Gossan) makes it difficult for the team to underground mines. Based on historical data, during the year of 2010 (up to 17th November), Mine Electrical planners have processed about 25,000 work orders, equivalent to 78 work orders per day or 26 per shift. During January to April 2011, the number still range at average $77-78$ work orders (total 9300 ). It is estimated that with DOZ mine development and production, Big Gossan mine development and production, DMLZ and GBC development occurs simultaneously in 2011 to 2014, and will be added with DMLZ production kick-off starting 2015, total number requests per day that has to be managed will increase significantly by about $50 \%$ in 2015 . It equals about 120 work requests per day, 40 per shift, or double the capacity one planner can handle. These numbers presented in Table 12. By April, work requests from underground area make about $56 \%$ of total request received during 2011 .

Without the overload situation, the current system already has several flaws:

- high involvement of manual data input (by user, planner, engineering, action team)

- high redundancy (same email has to be forwarded several times) shift is required for a group.

- lost of information still occurred due to no feedback from action team after work has be adequate for the paste plant. The calculation is presented in Table 10. The result shows that $6 \mathrm{men} /$ been done, planner forget to update status etc. 
causing incompliance or severe delay

- high possibility of double record and double work order raised from the same email information

What the current system tries to achieve basically is the uniformity of customers' request through one door, which is the planner, to prevent backand-forth communication between users and field supervisors, the lost or lack of information due to each party's dependence on the others to maintain those information, the delay in execution due to wrong-directed information and to ensure that all requests are stored, maintained, reminded, updated and reported regularly. User will submi request using standard form, fill in the mandatory field and send the form back to planners. Planners will then verify the data, record in the database and raise work order. All fields in the database have to be filled in manually by planners with correct corresponding information, thus opening more possibility of fault or mistyping leading to the incompliance or delay.

Currently, the task of raising daily work order is handled by the shift planners, one person per shift, that have average ability to process about 15 to 20 work orders, subject to the complexity of each work orders, because some might need spare parts to be completed while others might need no parts; some might located in hazardous area where pre-work communication with area owne is required while others might located in nearby shops. For the moment, shift planners only available for underground area. For surface mine, due to very limited resources, all planners are on steady day basis, manage PM, inspection and corrective maintenance work orders, also manage the part inventory.

\section{Development and Organization Strategy}

To make good improvement actions, an organization needs to have indicators to measure its performance properly and accurately. At the moment, there are five KPIs used in Mine Maintenance division to measure each department's performance. The current KPIs are on equipment fleet vs. owner base, certain owner, and it is the assigned-departments' responsibility to achieve the target.

These KPIs can't recognize other sections' contribution, although in reality most of the equipments successful maintenance programs are result of collaborative acts of several departments. The worst disadvantage for Mine Electrical happens in underground. Underground electrical KPIs are calculated only for equipments they "owned": switchgears, load centers, RMUs, VCBs, and transformers, while their work and dedication in performing maintenance for rock breakers, loading points, electric drills, ventilation fans, compressors, over head cranes, service trams, hoists and many others will not be recorded as their achievement, but rather it will contribute positively to the owner of those equipments. For example, every time a drill is on PM schedule, mechanic and electrician work together on the machine. Automatically, out of whatever KPI achievement is, 50\% contributed by the electrical group. The similar thing applied for KPI Actual Man Hours for Planned Work. Say, PM work orders contribute about $60 \%$ of the total work order of the drills. Then for the manpower works on PM activities alone, electrical group contributed about $20 \%-30 \%$ of the KPI achievement. Unfortunately, for this issue it is impossible to be repair, because system (Ellipse) limitation, where for one equipment, there can only be one reference for each of the KPI. Modification has suggested, to change the KPI from equipmentbased to work-group-based, to have a system better and fairer in describing a department's true performance.

The most important thing to be addressed is Mine Electrical service works performance indicator. As far as the Mine Electrical management concern, five KPIs implemented has failed to measure most of the department's service-nature duties, because the object has different characteristic from other equipments that are maintained by the rest of maintenance departments. There is a KPI to measure Scheduled WO Compliance (was Backlog Compliance), that suppose to describe how many of the scheduled works within period $\mathrm{X}$ that are completed also during period $\mathrm{X}$. To be considered as "planned work", a work order must be raised before period $X$ starts, maximum at 18:00 on $X-1$ day. The time frame is shown in Figure 5.

This is where the weakness of the logic lies, because any work order raised within period $\mathrm{X}$ to be executed during the same period (and comply), will be considered as unplanned, thus will not be counted in this KPI. In fact, this event will decrease department achievement on KPI Planned Work Order Raised. But actually the case is, when discussing about service work, the important thing is not whether it is planned or not, but more like the service level or service quality, such as: responsiveness, reliability, assurance that reflected in customer's satisfaction. In reality, a customer might ask for a service early in the morning to be done in the evening or in the next day or even in the next month. System limitation that strictly differ planned and unplanned work due to KPI parameter requirement may be unable to accommodate new KPI in service works. Not only that the creation of new KPI will enable the fairer and better judgment of Mine Electrical performance, it will also increase the moral of the crew, because they will feel that their hard work in the field is appreciated in a more appropriate way and it will encourage them to do better in the future

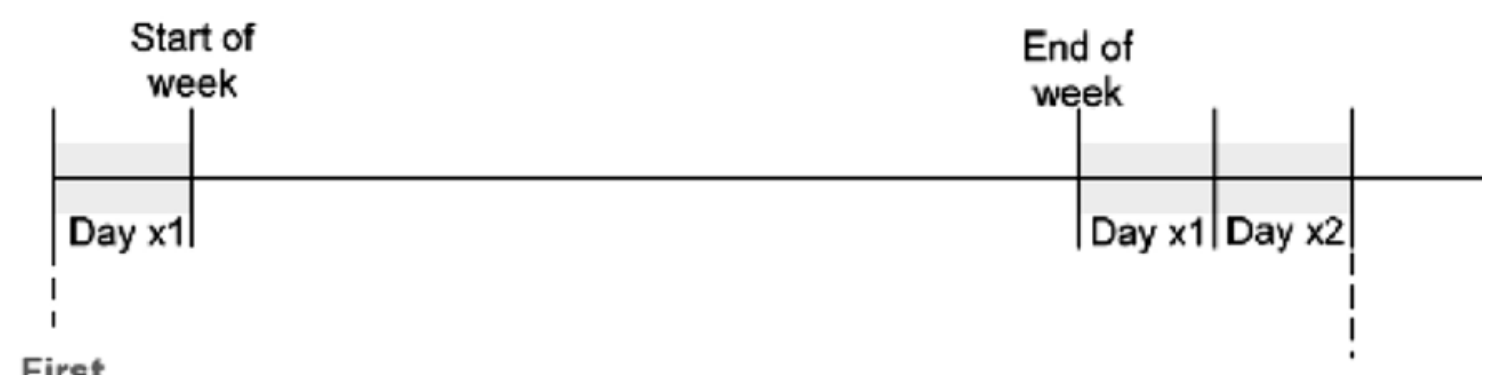

Figure 5. Time Frame of KPI Data Acquisition

\section{MANAGERIAL IMPLICATIONS}

\section{osed Solutions}

The overall capacity of Mine Electrical operations is determined by the number of equipment and the size of area that require their services. There are gaps, first in the current fulfillment between the approved manpower requirement and actual in the field, and the second in the increase of underground area manpower and the decrease of surface area manpower. Manpower number is very important to ensure that adequate resources available for al the teams to be able to achieve their targets. Firs option to be considered is to fill the gap with new hires and do lay-off as necessary; Second option will be to fill the gap with local contractor/regular employee provider; Third option will be to fill gap with professional/skilled contractors; Fourth option is to relocate manpower from Grasberg open-pit area to underground mines area as per manpower requirement.

The decision of work request management system is important because good strategy at this point of time will influence the performance of the whole group during the transition period. Because half of the department's working load is the service-type jobs where success factors include: information quality, responsiveness, dependability and the service quality itself. With the high level of manua handling in the current system, a vision of proces technology usage on the issue should be considered. To improve performance in the long run, there are three alternatives that can be selected: As-is condition, using the conventional system 
using standard form in spreadsheet and email as main communication channel; Collaborate with Management Information System (MIS) department to develop online call center/work request management system; Develop new webbased and database system by internal resource using existing tools.

The presence of proper performance indicator will enable an organization's performance to be described and measured fairer and better. This point of time is critical to make the decision, because proper KPI will also help management of Mine Electrical and also Mine Maintenance to have better view of the performance and determine work requirements in the future. First solution to conside is to maintain the as-is condition, using only the five KPIs and measure only for jobs related to equipments. Second solution is to modify the logic in the current KPIs to accommodate service-based works. Third, new KPI created with parameters derived from a known standard to measure service level or service quality or other common standard for service organization.

In the QSPM, weights for each performance objective were determined from data and discussion with key members, resulting with the following: quality $(30 \%)$, speed $(25 \%)$, dependability $(20 \%)$, cost $(15 \%)$, and flexibility (10\%). There was also risk of loss sales opportunity cost that should be considered, derived from one draw point inability to produce in a day ( $\$ 64,123$ - note: there are 125 active draw points) and one shovel failure to operate in a day ( $\$ 788,199$ - note: there are 20 shovels). Results of analysis are shown in Table 13

In this project, the decision taken is to combine alternatives 3 and 4 into one integrated strategy, which is by using the skilled contractors to fill in the current manpower shortage, and subject to contractor's performance, also for the upcoming years while manpower relocation will be more used to cover the dynamic decrease and increase of manpower requirement in surface mine and underground respectively. Having analyzed the department's objectives and situation, they are in line with contracting goals, presented by Levitt in The Handbook of Maintenance Management (2009: 121), which are to get maintenance work executed at higher quality, faster, safer or at lower cost than it would be possible with own resources; allows organization to maintain profit margins during downturns as contractor's people can be sent home without severance or adverse publicity; and to concentrate talent, energy, resources into core competencies area.

Dependability, speed and quality are very important factors of the online call center. With the system implemented, data lost can be minimized or even eliminated, thus ensuring that all customers requests, especially ones related to panels, draw points, draw bells and tunnels development, are completed as per required with no significant delays, minimizing also the loss opportunity incurred. Delays in three to five draw points per day can cause loss opportunity of $\$ 128,000$ to $\$ 192,000$.

The decision on this issue is mainly focused for the long-run operations of the department. Most users might be satisfied for how Mine Electrical provide service to them, but such acknowledgement is very hard to quantify if it's based only on personto-person communication between supervisors in the field and it's also hard to present it as evidence of performance without the proper system to accommodate it. So, the decision to create new KPI should be welcomed by the team, because it will give them a target and reference on how to provide service in the future to the customers. All results were then mapped to the operations strategy matrix presented in Appendix 3

In the capacity strategy, hiring skilled contractors will increase the quality and speed of the workforce significantly because this decision enable department to cut the time required on people development. The effect to the first two performance objectives is similar from the decision to relocate manpower from Grasberg to underground, because most of the manpower that will be sent to underground will mostly hor than five years experience thus giving them a good base to broaden the knowledge in underground area. Combined total manpower will provide department with resources as forecasted, making dependability and flexibility easier to achieve. The trade-off is on cost, because skilled contractors

require very high fee compared to other alternatives. his fact fortunately is counterbalanced by option 4 , where almost no cost will be incurred. Overall, this decision should able to improve performance in the future.

In the process technology strategy, the use of more advanced information technology (IT) for work request management system in the form of online
Table 13. Pros-Cons Overall Capacity Alternative Solutions

\begin{tabular}{|c|c|c|c|c|}
\hline No & Alternatives & Prerequisite & Pros & Cons \\
\hline \multirow[t]{4}{*}{1} & \multirow[t]{4}{*}{$\begin{array}{l}\text { New Hires } \\
\text { and Lay-Offs }\end{array}$} & $\begin{array}{l}\text { External } \\
\text { manpower } \\
\text { resources pool }\end{array}$ & $\begin{array}{l}\text { fres and strong motivated new } \\
\text { employees }\end{array}$ & $\begin{array}{l}\text { Extended cost and time for } \\
\text { hiring especially for training }\end{array}$ \\
\hline & & \multirow{3}{*}{$\begin{array}{l}\text { Good mutual } \\
\text { agreement terms }\end{array}$} & \multirow{3}{*}{$\begin{array}{l}\text { manpower requirement } \\
\text { independence on each area }\end{array}$} & Cost of Compensation \\
\hline & & & & $\begin{array}{l}\text { Complaints from the fired } \\
\text { employees }\end{array}$ \\
\hline & & & & Hard to find skilled freshmer \\
\hline \multirow[t]{4}{*}{2} & \multirow{4}{*}{$\begin{array}{l}\text { Local } \\
\text { Contractor }\end{array}$} & \multirow{4}{*}{$\begin{array}{l}\text { Reliable } \\
\text { manpower } \\
\text { providers }\end{array}$} & Averagely lower cost & Low skill and experience \\
\hline & & & $\begin{array}{l}\text { Provider usually have many } \\
\text { manpower resources ready to } \\
\text { work }\end{array}$ & $\begin{array}{l}\text { Training required for safety, } \\
\text { area-specific tools and } \\
\text { equipments, trade }\end{array}$ \\
\hline & & & $\begin{array}{l}\text { Providers already have had } \\
\text { contracts with PTFI }\end{array}$ & $\begin{array}{l}\text { Most of the contractors } \\
\text { asked to be transfered to } \\
\text { PTFI }\end{array}$ \\
\hline & & & & $\begin{array}{l}\text { User still have to deal with } \\
\text { employment-related matters }\end{array}$ \\
\hline \multirow[t]{4}{*}{3} & \multirow[t]{4}{*}{$\begin{array}{l}\text { Skilled } \\
\text { Contractors }\end{array}$} & $\begin{array}{l}\text { Proven and } \\
\text { qualififed } \\
\text { manpower } \\
\text { contractor } \\
\end{array}$ & $\begin{array}{l}\text { Qualified and experience } \\
\text { workforce }\end{array}$ & \multirow[t]{4}{*}{ Higher fee } \\
\hline & & \multirow{3}{*}{$\begin{array}{l}\text { Long-term } \\
\text { contract to ensure } \\
\text { the supply of } \\
\text { manpower }\end{array}$} & $\begin{array}{l}\text { No more training time required } \\
\text { except for safety-related }\end{array}$ & \\
\hline & & & $\begin{array}{l}\text { Users only deal with job } \\
\text { assignment; employment deal } \\
\text { by contractor management }\end{array}$ & \\
\hline & & & $\begin{array}{l}\text { Unlikely to ask for PTFI } \\
\text { employee status }\end{array}$ & \\
\hline \multirow[t]{3}{*}{4} & \multirow[t]{3}{*}{$\begin{array}{l}\text { Manpower } \\
\text { Relocation }\end{array}$} & \multirow{3}{*}{$\begin{array}{l}\text { Comprehensive } \\
\text { area specific work } \\
\text { training to prepare } \\
\text { manpower from } \\
\text { Grasberg }\end{array}$} & $\begin{array}{l}\text { Employees already } \\
\text { accustomed to department's } \\
\text { culture and environment }\end{array}$ & $\begin{array}{l}\text { Not all employee willing to } \\
\text { be relocated to undergrounc }\end{array}$ \\
\hline & & & No so many training needed & \multirow{2}{*}{$\begin{array}{l}\text { Lack of motivation due to } \\
\text { saturated feeling in long- } \\
\text { serving employees }\end{array}$} \\
\hline & & & $\begin{array}{l}\text { No extended cost for hiring/ } \\
\text { firing }\end{array}$ & \\
\hline
\end{tabular}




\section{Table 14. QSPM of Alternative Solutions for Overall Capacity Strategy}

\begin{tabular}{lccccccccc}
\hline \multirow{2}{*}{ Criterion } & \multirow{2}{*}{ Weight } & \multicolumn{2}{c}{ Alternative I } & \multicolumn{2}{c}{ Alternative II } & \multicolumn{2}{c}{ Alternative III } & \multicolumn{2}{c}{ Alternative IV } \\
\cline { 2 - 11 } & & AS & TAS & AS & TAS & AS & TAS & AS & TAS \\
\hline Quality & 0.30 & 2 & 0.6 & 1 & 0.3 & 4 & 1.2 & 3 & 0.9 \\
\hline Speed & 0.25 & 2 & 0.5 & 2 & 0.5 & 4 & 1 & 3 & 0.75 \\
\hline Dependability & 0.20 & 1 & 0.2 & 2 & 0.4 & 3 & 0.6 & 3 & 0.6 \\
\hline Cost & 0.15 & 2 & 0.3 & 4 & 0.6 & 1 & 0.15 & 4 & 0.6 \\
\hline Flexibility & 0.10 & 3 & 0.3 & 2 & 0.2 & 2 & 0.2 & 3 & 0.3 \\
\hline STAS & & & 1.90 & & 2.00 & & 3.15 & & 3.15 \\
\hline
\end{tabular}

Table 15. Pros-Cons Work Request Management Alternative Solutions

\begin{tabular}{|c|c|c|c|c|}
\hline No & Alternatives & Prerequisite & Pros & Cons \\
\hline \multirow[t]{5}{*}{1} & \multirow[t]{5}{*}{$\begin{array}{l}\text { As-Is Condi- } \\
\text { tion }\end{array}$} & \multirow[t]{5}{*}{ Not needed } & $\begin{array}{l}\text { Internal team and users are fami- } \\
\text { liar with the system }\end{array}$ & $\begin{array}{l}\text { Too many manual handling of } \\
\text { information }\end{array}$ \\
\hline & & & No extended cost needed & Events of information lost \\
\hline & & & \multirow[t]{3}{*}{ No development time required } & $\begin{array}{l}\text { Unnecessary data flow redun- } \\
\text { dancy }\end{array}$ \\
\hline & & & & $\begin{array}{l}\text { Different dara handling/treat- } \\
\text { ment }\end{array}$ \\
\hline & & & & $\begin{array}{l}\text { Back-and-forth question from } \\
\text { user }\end{array}$ \\
\hline \multirow[t]{7}{*}{2} & \multirow[t]{7}{*}{$\begin{array}{l}\text { Collaboration } \\
\text { with MIS }\end{array}$} & $\begin{array}{l}\text { Approval of MIS and } \\
\text { Mine Maintenance } \\
\text { management }\end{array}$ & $\begin{array}{l}\text { Proven system in order depart- } \\
\text { ments }\end{array}$ & $\begin{array}{l}\text { Additional time and cost for } \\
\text { development }\end{array}$ \\
\hline & & \multirow{6}{*}{$\begin{array}{l}\text { Feasibility study of } \\
\text { the current condi- } \\
\text { tion }\end{array}$} & $\begin{array}{l}\text { Many features for future deve- } \\
\text { lopment }\end{array}$ & $\begin{array}{l}\text { Socialization phase internally } \\
\text { and to users }\end{array}$ \\
\hline & & & $\begin{array}{l}\text { User can check status by their } \\
\text { own }\end{array}$ & \multirow[t]{5}{*}{$\begin{array}{l}\text { Development time depend on } \\
\text { other department's resources }\end{array}$} \\
\hline & & & Infrastructure is available & \\
\hline & & & Standard process flow & \\
\hline & & & $\begin{array}{l}\text { Minimal human intervention } \\
\text { regarding data input }\end{array}$ & \\
\hline & & & $\begin{array}{l}\text { Most users already familiar with } \\
\text { similar call centers by other } \\
\text { departments }\end{array}$ & \\
\hline \multirow[t]{4}{*}{3} & \multirow[t]{4}{*}{$\begin{array}{l}\text { Develop sys- } \\
\text { tem internally }\end{array}$} & \multirow[t]{4}{*}{$\begin{array}{l}\text { Comprehensive skill } \\
\text { and knowledge in IT }\end{array}$} & $\begin{array}{l}\text { Customized to the needs of the } \\
\text { department }\end{array}$ & $\begin{array}{l}\text { Hard to estimate development } \\
\text { time as internal resources } \\
\text { don't have proper skill and } \\
\text { experience }\end{array}$ \\
\hline & & & \multirow[t]{3}{*}{$\begin{array}{l}\text { No need to depend on other } \\
\text { department's resources }\end{array}$} & $\begin{array}{l}\text { More time needed to repair } \\
\text { the bug }\end{array}$ \\
\hline & & & & $\begin{array}{l}\text { Users still need time to accus- } \\
\text { tom to the new system }\end{array}$ \\
\hline & & & & $\begin{array}{l}\text { Socialization phase internally } \\
\text { and to users }\end{array}$ \\
\hline
\end{tabular}

Table 16. QSPM of Alternative Solutions for Work Request Management

\begin{tabular}{lccccccccc}
\hline \multirow{2}{*}{ Criterion } & \multirow{2}{*}{ Weight } & \multicolumn{2}{c}{ Alternative I } & \multicolumn{2}{c}{ Alternative II } & \multicolumn{2}{c}{ Alternative III } & \multicolumn{2}{c}{ Alternative IV } \\
\cline { 2 - 11 } & & AS & TAS & AS & TAS & AS & TAS & AS & TAS \\
\hline Quality & 0.30 & 2 & 0.6 & 1 & 0.3 & 4 & 1.2 & 3 & 0.9 \\
\hline Speed & 0.25 & 2 & 0.5 & 2 & 0.5 & 4 & 1 & 3 & 0.75 \\
\hline Dependability & 0.20 & 1 & 0.2 & 2 & 0.4 & 3 & 0.6 & 3 & 0.6 \\
\hline Cost & 0.15 & 2 & 0.3 & 4 & 0.6 & 1 & 0.15 & 4 & 0.6 \\
\hline Flexibility & 0.10 & 3 & 0.3 & 2 & 0.2 & 2 & 0.2 & 3 & 0.3 \\
\hline STAS & & & 1.90 & & 2.00 & & 3.15 & & 3.15 \\
\hline
\end{tabular}

Table 17. Pros-Cons KPI Alternative Solutions

\begin{tabular}{|c|c|c|c|c|}
\hline No & Alternatives & Prerequisite & Pros & Cons \\
\hline \multirow[t]{2}{*}{1} & \multirow[t]{2}{*}{$\begin{array}{l}\text { As-Is } \\
\text { Condition }\end{array}$} & \multirow[t]{2}{*}{ Not needed } & \multirow[t]{2}{*}{$\begin{array}{l}\text { No time and cost required } \\
\text { for new KPI development }\end{array}$} & $\begin{array}{l}\text { Inability to represent } \\
\text { service-based works }\end{array}$ \\
\hline & & & & $\begin{array}{l}\text { Inability to measure true } \\
\text { performance }\end{array}$ \\
\hline \multirow[t]{3}{*}{2} & \multirow[t]{3}{*}{$\begin{array}{l}\text { Modification } \\
\text { of current KPI }\end{array}$} & \multirow{3}{*}{$\begin{array}{l}\text { Discussion of responsible } \\
\text { parties to find opprtunities } \\
\text { for logic modification to } \\
\text { accommodate service- } \\
\text { based works }\end{array}$} & $\begin{array}{l}\text { Some parts of the service- } \\
\text { based works might be } \\
\text { covered }\end{array}$ & \multirow{2}{*}{$\begin{array}{l}\text { Due to modification of } \\
\text { existing system, not all the } \\
\text { required parameter can b } \\
\text { covered }\end{array}$} \\
\hline & & & System ready to be used & \\
\hline & & & $\begin{array}{l}\text { Almost all people alread } \\
\text { familiar with current KPIs }\end{array}$ & $\begin{array}{l}\text { Modified calculation } \\
\text { logic might impact to } \\
\text { other department's KPI } \\
\text { translation }\end{array}$ \\
\hline \multirow[t]{3}{*}{3} & \multirow[t]{3}{*}{$\begin{array}{l}\text { Create new } \\
\text { KPI }\end{array}$} & $\begin{array}{l}\text { Approval from } \\
\text { Mine Maintenance } \\
\text { management }\end{array}$ & $\begin{array}{l}\text { Represent true } \\
\text { performance }\end{array}$ & $\begin{array}{l}\text { KPI Development and } \\
\text { perfecting requires time }\end{array}$ \\
\hline & & $\begin{array}{l}\text { Task force to handle } \\
\text { project or give } \\
\text { responsibility to OpEx } \\
\text { team }\end{array}$ & $\begin{array}{l}\text { Cover all aspects required } \\
\text { to measure service } \\
\text { organization performance }\end{array}$ & \multirow[t]{2}{*}{$\begin{array}{l}\text { Socialization to all team } \\
\text { involved }\end{array}$} \\
\hline & & $\begin{array}{l}\text { Comprehensive study/ } \\
\text { understanding of some } \\
\text { standard in the world }\end{array}$ & $\begin{array}{l}\text { Act as reference for future } \\
\text { decision making }\end{array}$ & \\
\hline
\end{tabular}

Table 18. QSPM of Alternative Solutions for KPI

\begin{tabular}{lccccccc}
\hline \multirow{2}{*}{ Criterion } & \multirow{2}{*}{ Weight } & \multicolumn{2}{c}{ Alternative I } & \multicolumn{2}{c}{ Alternative II } & \multicolumn{2}{c}{ Alternative III } \\
\cline { 2 - 8 } & & AS & TAS & AS & TAS & AS & TAS \\
\hline Quality & 0,30 & 2 & 0,6 & 2 & 0,6 & 4 & 1,2 \\
\hline Speed & 0,25 & 2 & 0,5 & 2 & 0,5 & 3 & 0,75 \\
\hline Dependability & 0,20 & 1 & 0,2 & 2 & 0,4 & 3 & 0,6 \\
\hline Cost & 0,15 & 4 & 0,6 & 3 & 0,45 & 2 & 0,3 \\
\hline Flexibiity & 0,10 & 1 & 0,1 & 2 & 0,2 & 1 & 0,1 \\
\hline STAS & & & 2 & & 2,15 & & 2,95 \\
\hline
\end{tabular}


web-base call center will have positive effect on quality (better service quality; complete information leads to higher conformance of request), speed (user-friendly menu makes it easier for user to submit request; simple process and approval flow with minimal data redundancy makes it easier for planners to process the request), and dependability (complete request data including user-proposed required date enable planner and action team to estimate job duration better and when required, update that information to reschedule work under users approval).

For KPI, it is important as the first step toward improvement process. Continuous improvement based on the weekly KPI will impact mainly to quality, speed and dependability. All those will be traded-off with cost for KPI creation and development. No definite impact on the flexibility.

\section{Implementation Plan}

Detail implementation plan is given in Appendix 4.

Resources required during this phase are:

- Cost to hire skilled contractors is very high, but it is expected that they can provide high quality works. From two company references available, Mine Electrical has to pay between $\$ 901,047$ to $\$ 1,414,217$ in a year to fulfill about 43 current vacant positions. These contractors will be given the task in power distribution in both areas that requires skilled, tough and speedy crews to cope with the high expectation from customers.

- Manpower relocation from Grasberg to underground requires minimum cost. Cost incurred will be for underground-specific PPE (caplamp, Savox, respirator). A small team of staff planners is needed to manage the relocation.

- Collaboration with MIS to develop Mine Electrical Online Call Center requires assigned person from department and a technical expert, as the contact persons to MIS. Internal resources will be needed then, to run the system (call center officer), train the people and conduct socialization. An estimated cost of $\$ 6,000$ will incur as the cost to MIS department.

Development of new KPI for service works requires a formation of task force, with assigned person from Mine Electrical involve in it, together with OpEx team and Maintenance Engineering staff. No cost will incur because OpEx have their contract PTFI paid as a package. An estimated $\$ 6,000$ will be required for MIS to merge with existing online KPI.

\section{CONCLUSION}

In this paper, strategy formulation of Mine Electrical department was performed using operations strategy model of Slack and Lewis (2008). The need of new strategy itself was trigged by shifting of mine focus from Grasberg open-pit centered to underground mines. Business issue exploration confirmed the three issues surfaced needed to be taking care of due to their impact to long-term operations. The availability of adequate manpower based on requirement forecast is important as the main resource to perform daily tasks and achieve performance target. While for work request management, a reliable, trusted and user-friendly system is required to improve quality, speed and dependability of the works requested by customers. Minimum error and processing time can also increase job completion and avoid delay that might lead to loss sales opportunity at PTFI level. The existence of proper performance indicator is mandatory for an organization to benchmark its performance to a certain standard that in the end will make ways for improvement actions based on the KPI result.

The project though still has room for further study, for example for skilled contractor's database. More than two samples will increase the competition and with appropriate bid process, Mine Electrical might get a better price offer. The paper limited the scope of decision on KPI only to whether creating new one or not. There's opportunity in the future to assess options of what reference or standard that can be used. In the future, during the transition period, when there's need of another strategy change, there's possibility that supply network (out of scope in this paper) become an important

, especially regarding to the availability of the Top 50 and Top 100 critical part in Mine Electrical.

\section{REFERENCES}

Beckman, S. \& Rosenfield, D. (2008). Operations Strategy: Competing in the $21^{\text {st }}$ Century. New York: McGraw-Hill/Irwin. Boric, J. (2011). Investing in Copper - A Bullish Scenario for Copper. Retrieved on 30 March 2011 from http://dailyreckoning com/investing-in-coppe

Freeport McMoRan Copper \& Gold Inc. (2011). 2010 Annual Report Form 10-K.

Hariyadi, A. (2011). Personal interview by Rafiq Sulistyo, Tembagapura: 10 March 2011,

.ernational Labor Organization (LO), n.d., Act of the Republic of Indonesia Number 13 Year 2003 Concerning Manpower. Retrieved on 11 May 2011 from http://www.ilo.org/dyn/natlex/docs/SERIAL/64764/56412/F861503702/idn64764.PDF

Levitt, J. (2009). Handbook of Maintenance Management. New York: Industrial Press.

MBA Tutorials. (2009). Quantitative Strategic Planning Matrix (QSPM). Retrieved on 11 May 2011 from http://www.mbatutorials.com/strategy/230-quantitative-strategic-planning-matrix-qspm.html

PT Freeport Indonesia. (2009). Collective Labor Agreement 2009-2011.

PT Freeport Indonesia. (2009). Industrial Relations Guidebook 2009-2011.

PT Freeport Indonesia. (2008). Tour Companion 2009.

PT Freeport Indonesia (n.d.). Sekilas Tentang PT Freeport Indonesia, Retrieved on 3 March 2011 from http://www ptfi.co.id/

Slack, N. \& Lewis, M. (2008). Operations Strategy. New Jersey: Prentice Hall.

radingstocks.me (5 January 2011). World Copper Consumption Supply and Demand in 2011. Retrieved on 30 March 201 from http://radingstocks.me/world-copper-consumption-supply-and-demand-in-2011

US Inffation Calculator (n.d.). The Inffation Calculator, Retrieved on 30 March 2011 rrom http.//usinflationcalculator.com. Wheelen, T.L., and Hunger, J.D. (2008). Strategic Management and Business Policy. New Jersey: Prentice Hall. 


\section{Appendix 1. Strategic Factors Analysis Summary}

\begin{tabular}{|c|c|c|c|c|}
\hline No. & IFAS & Weight & Rating & Value \\
\hline & Strength & & & \\
\hline 1 & Strong organization culture: safe production & 0,1 & 4 & 0,4 \\
\hline 2 & $\begin{array}{l}\text { Huge ore deposits and second-ranked producer in the } \\
\text { world }\end{array}$ & 0,2 & 5 & 1 \\
\hline 3 & Lower production cost among similar producer & 0,15 & 4 & 0,6 \\
\hline 4 & $\begin{array}{l}\text { Skilled employees through competency-based } \\
\text { development }\end{array}$ & 0,1 & 3 & 0,3 \\
\hline \multirow[t]{2}{*}{5} & $\begin{array}{l}\text { Thorough and complete Corporate Social } \\
\text { Responsibility programs }\end{array}$ & 0,05 & 4 & 0,2 \\
\hline & Weakness & & & \\
\hline 1 & Only one access road available from lowland to mine & 0,05 & 3 & 0,15 \\
\hline 2 & Extreme weather condition and remote mining area & 0,1 & 4 & 0,4 \\
\hline 3 & $\begin{array}{l}\text { Only have maximum until } 2041 \text { to conduct production } \\
\text { activities }\end{array}$ & 0,1 & 4 & 0,4 \\
\hline 4 & $\begin{array}{l}\text { Limited availability of accommodation for new } \\
\text { employees }\end{array}$ & 0,05 & 3 & 0,15 \\
\hline \multirow[t]{2}{*}{5} & Conditions and obligations in the Contract of Work & 0,1 & 4 & 0,4 \\
\hline & Total & 1 & & 1,00 \\
\hline \multirow[t]{2}{*}{ No. } & EFAS & Weight & Rating & Value \\
\hline & Opportunity & & & \\
\hline 1 & High commodity prices (steady increase since 2009) & 0,15 & 5 & 0,75 \\
\hline 2 & $\begin{array}{l}\text { High demand of copper especially from China, US and } \\
\text { India }\end{array}$ & 0,15 & 5 & 0,75 \\
\hline 3 & Estimated shorffall of copper supplies in 2011 and 2012 & 0,1 & 4 & 0,4 \\
\hline 4 & Looming inflation rate & 0,1 & 3 & 0,3 \\
\hline \multirow[t]{2}{*}{5} & $\begin{array}{l}\text { Technology breakthrough in mining support activities } \\
\text { and equipments }\end{array}$ & 0,05 & 3 & 0,15 \\
\hline & Threat & & & \\
\hline 1 & $\begin{array}{l}\text { Indonesia's political, economical and social } \\
\text { uncertainties }\end{array}$ & 0,1 & 4 & 0,4 \\
\hline 2 & Sporadic shootings terror to employees since July 2009 & 0,1 & 4 & 0,4 \\
\hline 3 & $\begin{array}{l}\text { Fluctuated commodity prices highly influential to } \\
\text { financial results }\end{array}$ & 0,05 & 4 & 0,2 \\
\hline 4 & Environmental issues & 0,1 & 4 & 0,4 \\
\hline \multirow[t]{2}{*}{5} & $\begin{array}{l}\text { Major risks that affect operation directly including } \\
\text { natural disasters, accidents, unusual weather } \\
\text { conditions, interruption of energy supply, wall failures, } \\
\text { rock slides or structural collapse in mines }\end{array}$ & 0,1 & 4 & 0,4 \\
\hline & Total & 1 & & 0,55 \\
\hline
\end{tabular}

Matrix for Appendix 1

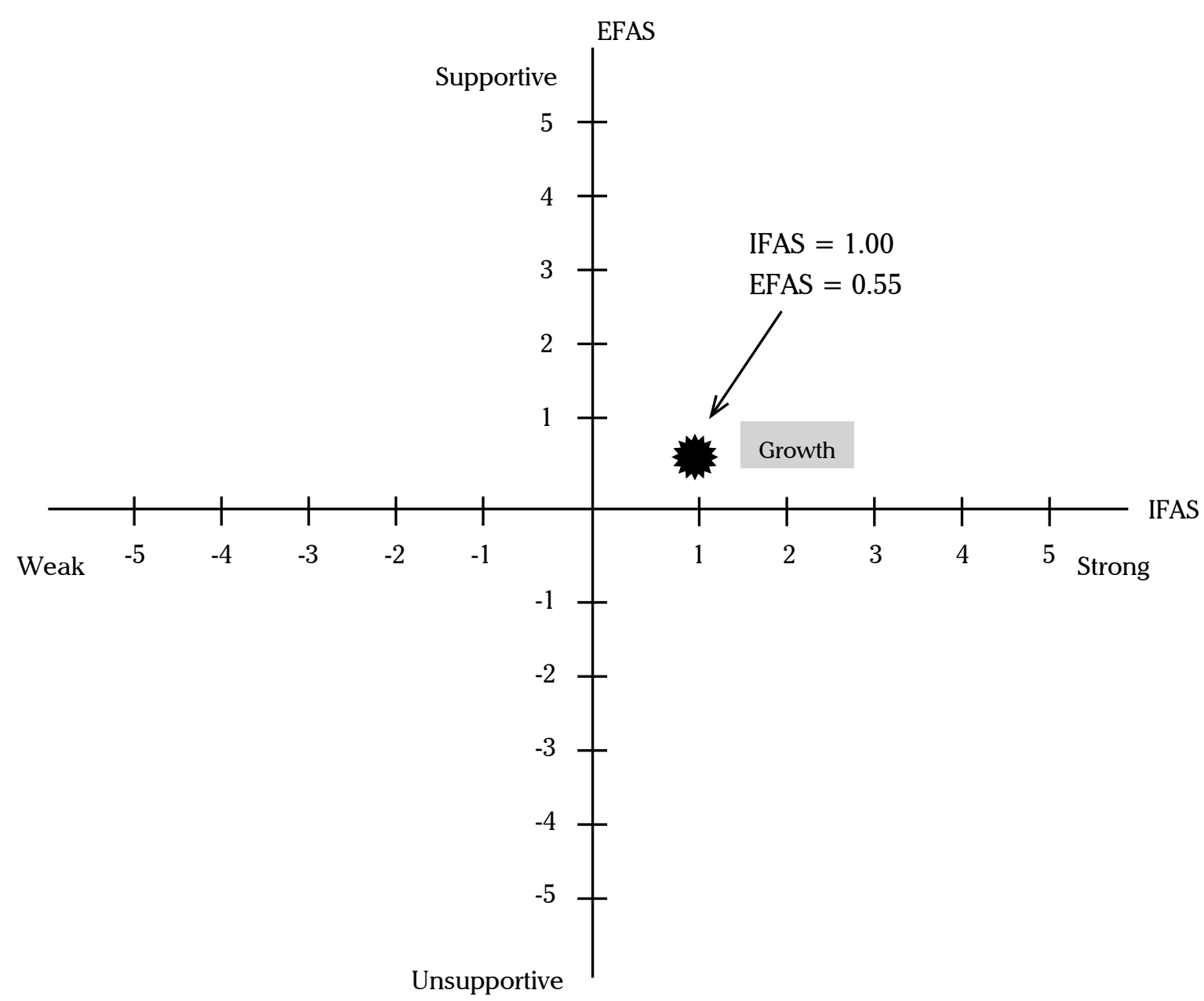




\begin{tabular}{|c|c|c|c|c|c|c|c|c|}
\hline Equipment/Group & $\begin{array}{c}2011 \\
\text { (actual) }\end{array}$ & $\begin{array}{l}2011 \\
\text { (ideal) }\end{array}$ & $2012 \mathrm{e}$ & $2013 \mathrm{e}$ & $2014 \mathrm{e}$ & $2015 \mathrm{e}$ & $2016 \mathrm{e}$ & $2017 \mathrm{e}$ \\
\hline & N/S & N/S & N/S & N/S & $\mathrm{N} / \mathrm{S}$ & $\mathrm{N} / \mathrm{S}$ & N/S & N/S \\
\hline \multicolumn{9}{|l|}{ UNDERGROUND ELECTRICAL } \\
\hline HV Power Distribution - Maintenance & 12 & 12 & 16 & 16 & 16 & 20 & 20 & 20 \\
\hline LV Power Distribution - Maintenance & 16 & 16 & 16 & 16 & 16 & 16 & 16 & 16 \\
\hline Fixed Plant - Shops \& Lamp Room & 8 & 8 & 8 & 8 & 8 & 8 & 10 & 10 \\
\hline $\begin{array}{l}\text { Tram, Hoist \& Paste Plant } \\
\end{array}$ & 28 & 32 & 32 & 32 & 32 & 32 & 32 & 32 \\
\hline Dispatch, Communications \& Instrumentation & 27 & 28 & 28 & 28 & 28 & 30 & 30 & 30 \\
\hline Big Gossan Power Distribution & 8 & 8 & 8 & 8 & 8 & 8 & 8 & 8 \\
\hline DMLZ Power Distribution & 8 & 8 & 8 & 8 & 8 & 12 & 12 & 12 \\
\hline GBC Power Distribution & 8 & 8 & 8 & 8 & 8 & 12 & 12 & 12 \\
\hline Expansion Mines Construction & 8 & 8 & 8 & 12 & 12 & 12 & 12 & 12 \\
\hline Axera 5 & 1 & 1 & 0 & 0 & 0 & 0 & 0 & 0 \\
\hline Axera 7 & 14 & 14 & 16 & 15 & 15 & 15 & 15 & 15 \\
\hline Axera T08-290 & 3 & 3 & 3 & 3 & 3 & 3 & 3 & 2 \\
\hline Axera T08-360 & 3 & 3 & 3 & 4 & 4 & 4 & 4 & 3 \\
\hline Cubex & 4 & 4 & 4 & 4 & 4 & 2 & 2 & 4 \\
\hline Robolter 5 & 2 & 2 & 4 & 3 & 2 & 2 & 2 & 2 \\
\hline Cabolter 7 & 3 & 3 & 3 & 3 & 3 & 3 & 3 & 3 \\
\hline Solo 7-15 & 2 & 2 & 3 & 3 & 5 & 7 & 7 & 7 \\
\hline Compressor & 3 & 3 & 3 & 4 & 4 & 4 & 4 & 4 \\
\hline Main Fans & 3 & 3 & 3 & 3 & 3 & 3 & 3 & 3 \\
\hline Auxiliary Fans & 6 & 6 & 6 & 6 & 6 & 8 & 8 & 8 \\
\hline Welding Machine & 3 & 3 & 3 & 3 & 3 & 3 & 3 & 3 \\
\hline Hi-Vac & 1 & 1 & 1 & 1 & 1 & 1 & 1 & 1 \\
\hline Lighting Plants & 1 & 1 & 1 & 1 & 1 & 1 & 1 & 1 \\
\hline Fixed Crane & 3 & 3 & 4 & 4 & 4 & 4 & 4 & 4 \\
\hline Rockbreakers & 8 & 8 & 8 & 9 & 10 & 10 & 11 & 12 \\
\hline Ore Chutes & 6 & 6 & 6 & 7 & 7 & 7 & 9 & 10 \\
\hline Remote Control Loaders & 5 & 5 & 5 & 6 & 6 & 6 & 6 & 6 \\
\hline MineGem Control Room & 2 & 2 & 2 & 2 & 2 & 2 & 2 & 2 \\
\hline Trolley Maintenance & 4 & 4 & 6 & 8 & 12 & 12 & 12 & 12 \\
\hline 36 Ton Locomotive & 9 & 9 & 9 & 15 & 15 & 15 & 15 & 18 \\
\hline 43 Ton ore Locomotive & 2 & 2 & 2 & 2 & 9 & 12 & 15 & 18 \\
\hline Battery Locomotives & 0 & 0 & 0 & 0 & 0 & 0 & 0 & 6 \\
\hline Battery Stations & 0 & 0 & 0 & 0 & 0 & 0 & 0 & 2 \\
\hline Planners & 4 & 11 & 12 & 13 & 13 & 14 & 15 & 15 \\
\hline Parts Runners & 12 & 8 & 8 & 9 & 9 & 10 & 10 & 11 \\
\hline VAT & 30 & 36 & 38 & 40 & 42 & 45 & 47 & 49 \\
\hline Subtotal Underground & 257 & 271 & 285 & 304 & 319 & 343 & 354 & 373 \\
\hline \multicolumn{9}{|l|}{$\underline{\text { SURFACE ELECTRICAL }}$} \\
\hline Power lines & 24 & 24 & 22 & 18 & 16 & 12 & 6 & 6 \\
\hline Cable Repair & 6 & 8 & 6 & 4 & 4 & 2 & 2 & 2 \\
\hline Surface Substation Mtce & 4 & 4 & 4 & 4 & 4 & 4 & 4 & 4 \\
\hline Fixed Facility Mtce & 9 & 12 & 9 & 9 & 6 & 6 & 6 & 6 \\
\hline Dispatch technician & 7 & 8 & 8 & 6 & 5 & 3 & 2 & 2 \\
\hline Rotation & 14 & 16 & 12 & 12 & 8 & 8 & 6 & 6 \\
\hline Planners & 5 & 5 & 5 & 4 & 4 & 3 & 2 & 2 \\
\hline Shvl Electrical & 27 & 32 & 32 & 25 & 25 & 15 & 13 & 5 \\
\hline Parts Runner/ Facility Mtce & 4 & 4 & 4 & 4 & 3 & 3 & 2 & 2 \\
\hline \multirow[b]{2}{*}{ Subtotal Grasberg } & 14 & 17 & 16 & 13 & 12 & 9 & 7 & 6 \\
\hline & 114 & 130 & 118 & 99 & 87 & 65 & 50 & 41 \\
\hline Total Mine Electrical & 371 & 401 & 403 & 403 & 406 & 408 & 404 & 414 \\
\hline Total Actual Non Staff & 328 & & & & & & & \\
\hline \multirow[t]{3}{*}{ Shortage } & 43 & & & & & & & \\
\hline & \multicolumn{2}{|c|}{$\begin{array}{l}\text { Delta from } \\
\text { previous year - UG }\end{array}$} & 14 & 19 & 15 & 24 & 11 & 19 \\
\hline & \multicolumn{2}{|c|}{$\begin{array}{l}\text { Delta from } \\
\text { previous year - } \\
\text { GRS }\end{array}$} & 12 & 19 & 12 & 22 & 15 & 9 \\
\hline
\end{tabular}

Appendix 3. Operations Strategy Matrix for Mine Electrical

\begin{tabular}{|c|c|c|c|c|c|}
\hline & \multicolumn{4}{|c|}{ Resource Usage } \\
\hline & & & & & \\
\hline \multirow{5}{*}{ 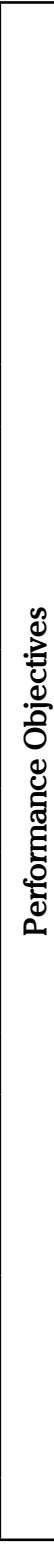 } & Quality & \begin{tabular}{|l}
$\begin{array}{l}\text { Hiring skilled } \\
\text { contractors to fill the } \\
\text { temporary quality gap }\end{array}$ \\
\\
Using skilled labor \\
from Grasberg \\
\\
$* * * *$
\end{tabular} & & $\begin{array}{l}\text { Complete and } \\
\text { consistent information } \\
\text { enhance preparation } \\
\text { and execution as per } \\
\text { required }\end{array}$ & 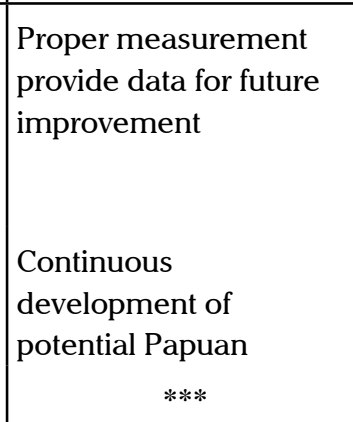 \\
\hline & Speed & 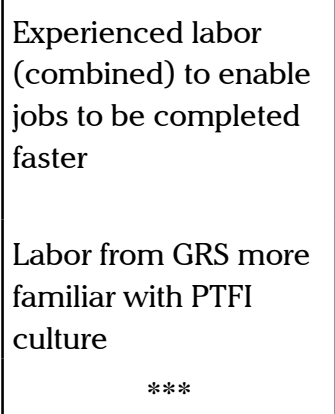 & & $\begin{array}{l}\text { Reduce in data } \\
\text { redundancy and } \\
\text { increase duration of } \\
\text { approval/data flow }\end{array}$ & $\begin{array}{l}\text { Accurate and routine } \\
\text { feedback enable } \\
\text { improvement made } \\
\text { faster in the following } \\
\text { period } \\
\text { More skilled employee } \\
\text { for faster job completion } \\
\\
\qquad * *\end{array}$ \\
\hline & Dependability & 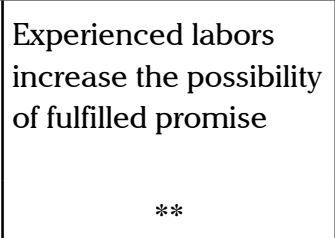 & & $\begin{array}{l}\text { Data kept properly } \\
\text { in online call center, } \\
\text { minimize/eliminate } \\
\text { data lost. } \\
\qquad * * *\end{array}$ & $\begin{array}{l}\text { Reliable feedback data } \\
\text { enable correction made } \\
\text { faster in the following } \\
\text { period }\end{array}$ \\
\hline & Flexibility & $\begin{array}{l}\text { Adequate labor enable } \\
\text { jobs to be rescheduled } \\
\text { or reassigned more } \\
\text { flexibly }\end{array}$ & & $\begin{array}{l}\text { Work request } \\
\text { managed better, } \\
\text { planner able to see } \\
\text { the bigger picture } \\
\qquad * *\end{array}$ & No definite effect \\
\hline & Cost & \begin{tabular}{|l|} 
High fee contractors \\
balanced with internal \\
resources \\
$\qquad * *$
\end{tabular} & & $\begin{array}{l}\text { Cost and time of } \\
\text { development but } \\
\text { worth for long-run } \\
*\end{array}$ & $\begin{array}{l}\text { Cost and time of } \\
\text { development but worth } \\
\text { for future decision } \\
\qquad * *\end{array}$ \\
\hline & & Capacity & $\begin{array}{c}\text { Supply } \\
\text { Network }\end{array}$ & Process Technology & $\begin{array}{c}\text { Development and } \\
\text { Organization } \\
\end{array}$ \\
\hline & & $\begin{array}{l}\text { Overall capacity } \\
\text { strategy by using } \\
\text { skilled contractors and } \\
\text { relocate manpower } \\
\text { from Grasberg to UG }\end{array}$ & & $\begin{array}{l}\text { Collaborative work } \\
\text { with MIS to develop } \\
\text { online call center }\end{array}$ & $\begin{array}{l}\text { Development of new } \\
\text { KPI to measure service- } \\
\text { based works }\end{array}$ \\
\hline & & & & & $\begin{array}{l}\text { Intensive development } \\
\text { of Papuan employees }\end{array}$ \\
\hline & & Decision Areas & & & \\
\hline
\end{tabular}


Appendix 4. Detail Implementation Plan

\begin{tabular}{|c|c|c|c|c|c|c|c|c|c|c|c|c|c|c|c|c|}
\hline \multirow{2}{*}{ ID } & \multirow{2}{*}{ Task Name } & \multirow{2}{*}{$\begin{array}{c}\text { Duration } \\
\text { (days) }\end{array}$} & \multirow{2}{*}{$\begin{array}{l}\text { Person in } \\
\text { Charge }\end{array}$} & \multicolumn{2}{|l|}{ July 1} & \multicolumn{3}{|c|}{ July 21} & \multicolumn{3}{|c|}{ August 11} & \multicolumn{2}{|c|}{ September 1} & \multicolumn{3}{|c|}{ September 21} \\
\hline & & & & \begin{tabular}{l|l}
$7 / 3$ & $7 / 10$
\end{tabular} & $7 / 17$ & $7 / 24$ & $7 / 31$ & $8 / 7$ & $8 / 14$ & $8 / 21$ & $8 / 28$ & $9 / 4$ & $9 / 11$ & $9 / 18$ & $9 / 25$ & $10 / 2$ \\
\hline 1 & Hire Skilled Contractors & 57 & Agung $\mathrm{H}$. & & & & & & & & & & & & & \\
\hline 2 & $\begin{array}{l}\text { Search available skilled labor } \\
\text { providers }\end{array}$ & 20 & Ferry E. & & & & & & & & & & & & & \\
\hline 3 & $\begin{array}{l}\text { Review bids/proposals and } \\
\text { determine winner }\end{array}$ & 5 & \begin{tabular}{|} 
Nano, Dadang, \\
Basuki, Rafiq
\end{tabular} & & & & & & & & & & & & & \\
\hline 4 & Create contracts & 15 & Contracts Dept. & & & & & & & & & & & & & \\
\hline 5 & Prepare work documents \& PPE & 5 & $\begin{array}{l}\text { Rafiq, Andy, } \\
\text { Rudi }\end{array}$ & & & & & & & & & & & & & \\
\hline 6 & Mobilize contractors to jobsite & 2 & Andy, Rudi & & & & & & & 7 & & & & & & \\
\hline 7 & $\begin{array}{l}\text { Conduct mandatory safety } \\
\text { induction and trainings }\end{array}$ & 10 & $\begin{array}{l}\text { Andy, Rudi, } \\
\text { QMS }\end{array}$ & & & & & & & & & & & & & \\
\hline 8 & $\begin{array}{l}\text { Relocate Manpower from GRS to } \\
\text { U/G }\end{array}$ & 27 & Rafiq S. & & & & & & & & & & & & & \\
\hline 9 & Prepare list of manpower & 15 & $\begin{array}{c}\text { Rafiq, Basuki, } \\
\text { Sijabat, Rudi } \\
\end{array}$ & & & & & & & & & & & & & \\
\hline 10 & $\begin{array}{l}\text { Cross-check data and determine } \\
\text { "to" locations }\end{array}$ & 10 & \begin{tabular}{|l|} 
Rafiq, Dadang, \\
Jarmanto, Andy
\end{tabular} & & & & & & & & & & & & & \\
\hline 11 & Prepare administrative data & 5 & Andy, Rudi & & & & & & & & & & & & & \\
\hline 12 & Send men to trainings & 10 & Andy, QMS & & & & & & & & & & & & & \\
\hline 13 & Prepare PPE & 5 & Sudjarwo, Andy & & & & & & & & & & & & & \\
\hline 14 & Start mobilization & 2 & $\begin{array}{c}\text { Irpan, Sudjar- } \\
\text { wo, Siswanto, } \\
\text { Mulyadin }\end{array}$ & & & & & & & & & & & & & \\
\hline 15 & $\begin{array}{l}\text { Collaborate with MIS to Develope } \\
\text { Online Call Center }\end{array}$ & 67 & Rafiq S; Gary S. & & & & & & & & & & & & & \\
\hline 16 & $\begin{array}{l}\text { Gain approfal from Mine Mainte- } \\
\text { nance and MIS Management }\end{array}$ & 3 & Agung, Gary & & & & & & & & & & & & & \\
\hline 17 & Kick-off meeting & 1 & Rafiq MIS & & & & & & & & & & & & & \\
\hline 18 & $\begin{array}{l}\text { Analyze business process, work } \\
\text { group, task catagory, approval } \\
\text { flow }\end{array}$ & 20 & Rafiq, Gary & & & & & & & & & & & & & \\
\hline 19 & $\begin{array}{l}\text { Review analysis and fine tune all } \\
\text { process }\end{array}$ & 20 & MIS & & & & & & & & & & & & & \\
\hline 20 & $\begin{array}{l}\text { Program the application and } \\
\text { conduct test run }\end{array}$ & 23 & MIS & & & & & & & & & & & & & \\
\hline 21 & Pilot test for limited users & 10 & $\begin{array}{l}\text { Rafiq, Andy, } \\
\text { Rudi }\end{array}$ & & & & & & & & & & & & & \\
\hline 22 & $\begin{array}{l}\text { Conduct internal socialization } \\
\text { and training }\end{array}$ & 10 & Andy, Rudi & & & & & & & & & & & & & \\
\hline 23 & Conduct external socialization & 10 & Rafiq, Gary & & & & & & & & & & & & & \\
\hline 24 & $\begin{array}{l}\text { Launch the Mine Electrical } \\
\text { Online Call Center }\end{array}$ & 2 & & & & & & & & & & & & & & \\
\hline 25 & Develop New KPI for Service Works & 91 & Opex Team & & & & & & & & & & & & & \\
\hline 26 & $\begin{array}{l}\text { Discussion and presentation to } \\
\text { upper management }\end{array}$ & 10 & Agung & & & & & & & & & & & & & \\
\hline 27 & $\begin{array}{l}\text { gain approval from Mine Mainte- } \\
\text { nance management }\end{array}$ & 3 & Agung, OpEx & & & & & & & & & & & & & \\
\hline 28 & Form task force & 3 & $\begin{array}{l}\text { OpEx, Rafiq, } \\
\text { Rizal }\end{array}$ & & & & & & & & & & & & & \\
\hline 29 & $\begin{array}{l}\text { Further study of available stan- } \\
\text { dard for reference }\end{array}$ & 10 & Task force & & & & & & & & & & & & & \\
\hline 30 & $\begin{array}{l}\text { Start working on the proposed } \\
\text { KPI }\end{array}$ & 20 & Task force & & & & & & & & & & & & & \\
\hline 31 & Socialize to Mine Electrical team & 5 & $\begin{array}{l}\text { Task force, } \\
\text { Rafiq }\end{array}$ & & & & & & & & & & & & & \\
\hline 32 & Conduct trial & 15 & $\begin{array}{l}\text { Task force, } \\
\text { Rizal }\end{array}$ & & & & & & & & & & & & & \\
\hline 33 & $\begin{array}{l}\text { Integrate new KPI to online KPI } \\
\text { calculation }\end{array}$ & 25 & Task force, MIS & & & & & & & & & & & & & \\
\hline
\end{tabular}

